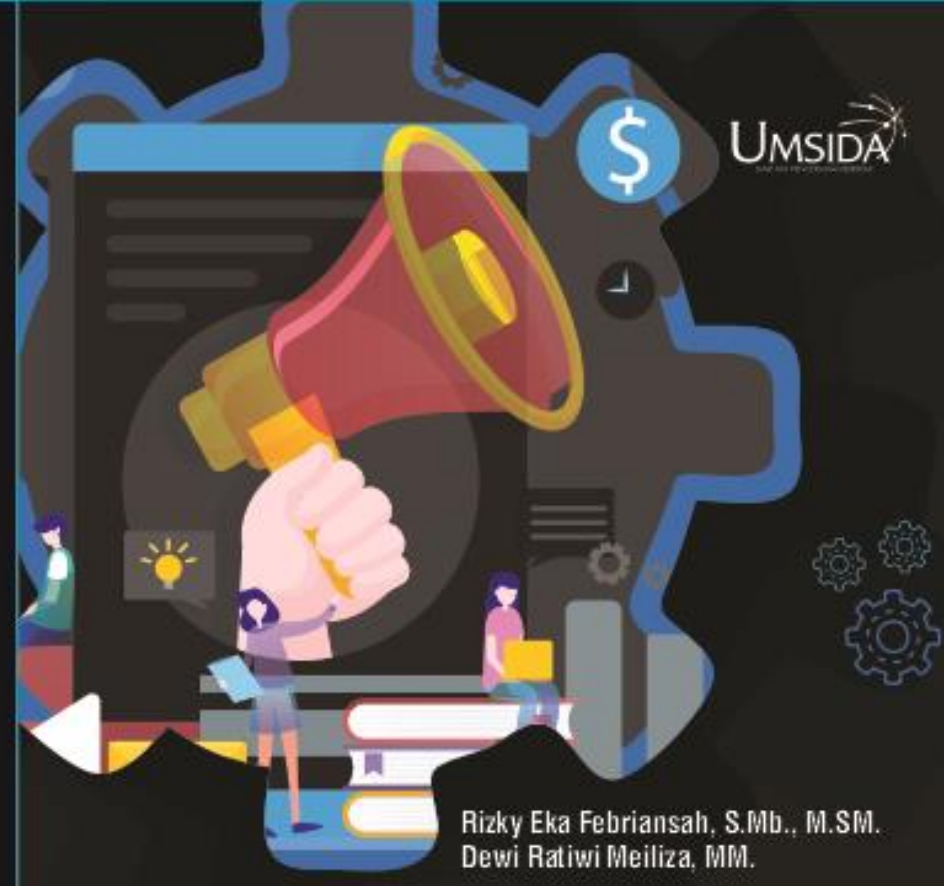

ISBN 978-623-6833-62-9 (PDF)

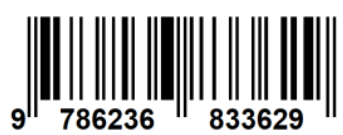

TEORI

PENGAMBILAN

KEPUTUSAN 


\title{
BUKU AJAR MATA KULIAH
}

\section{TEORI PENGAMBILAN KEPUTUSAN}

\author{
Oleh \\ Rizky Eka Febriansah, S.Mb., M.SM.
}

Dewi Ratiwi Meiliza, SE. MM.

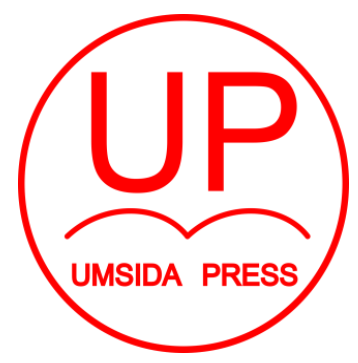

UNIVERSITAS MUHAMMADIYAH SIDOARJO

2020 


\section{BUKU AJAR}

\section{TEORI PENGAMBILAN KEPUTUSAN}

\section{Penulis :}

Rizky Eka Febriansah, S.Mb., M.SM.

Dewi Ratiwi Meiliza, SE. MM.

\section{ISBN :}

\section{8-623-6833-62-9}

\section{Editor :}

Sumartik, SE., MM.

Design Sampul dan Tata Letak :

Mochamad Nashrullah, S.Pd.

Amy Yoga Prajati, S.Kom.

\section{Penerbit :}

UMSIDA Press

Anggota IKAPI No.218/Anggota Luar Biasa/JTI/2019

Anggota APPTI No. 0020181092017

\section{Redaksi :}

Universitas Muhammadiyah Sidoarjo

Jl. Mojopahit No 666B

Sidoarjo, Jawa Timur

Cetakan pertama, September 2020

(C) Hak cipta dilindungi undang-undang

Dilarang memperbanyak karya tulis ini dengan suatu apapun tanpa ijin tertulis dari penerbit. 


\section{KATA PENGANTAR}

Puji syukur kehadirat Allah SWT atas segala anugerah dan rahmat-Nya, sehingga Buku Ajar Teori Pengambilan Keputusan untuk Prodi manajemen Fakultas Ekonomi dan Bisnis Universitas Muhammadiyah Sidoarjo ini dapat terselesaikan dengan baik. Buku Ajar Teori Pengambilan Keputusan ini terdiri dari 4 Bab Materi Perkuliahan, yang merupakan satu kesatuan materi yang dipelajari oleh mahasiswa secara menyeluruh dan tak terpisahkan selama satu semester karena merupakan satu kesatuan yang utuh dalam Capaian Kompetensi dari Teori Pengambilan Keputusan di Rencana Pembelajaran Semester. Buku Ajar Teori Pengambilan Keputusan Prodi Manajemen Fakultas Ekonomi dan Bisnis ini diterbitkan oleh Universitas Muhammadiyah Sidoarjo (UMSIDA) Press untuk kalangan sendiri. Buku Ajar ini merupakan buku terbitan edisi pertama yang tentunya masih butuh disempurnakan. Oleh karena itu, saran dan masukan oleh para pengguna sangat kami harapkan untuk kesempurnaan isi buku ajar ini di masa yang akan datang.

Sidoarjo, 31 Juli 2020

Penulis 


\section{DAFTAR ISI}

Halaman Sampul

Identitas Buku

Kata Pengantar

Daftar Isi

\section{BAB I Konsep Dasar Pengambilan Keputusan}
A. Definisi Keputusan__1
B. Tahap Pengambilan Keputusan__2
C. Proses Pengambilan Keputusan_3
D. Tujuan Dan Asumsi Pengambilan Keputusan_6
E. Konsep Pengambilan Keputusan_ 7
F. Masalah Pengambilan Keputusan_13
G. Perubahan Lingkungan yang Mengakibatkan Perubahan Keputusan__14

H. Dukungan Sistem Informasi_16

I. Gaya Pemikiran dan Persepsi_18

J. Model Pengambilan Keputusan yang Tak Terstruktur_21

K. Pengambilan Keputusan secara Berkelompok_21

L. Pengambilan keputusan dalam kondisi yang pasti dan tidak pasti__23

M. Soal-soal_26

\section{BAB II Business Plan dan Etika dalam Pengambilan Keputusan}

A. Pertimbangan Etika, tanggung jawab sosial, dan pandangan tentang rasional ekonomi__27

B. Pertimbangan Etika Dan Perilaku Organisasi__30

C. Kriteria etika dalam pengambilan keputusan__35

D. Pengambilan Keputusan Dalam Kondisi Konflik__39

E. Definisi Business Plan_42

F. Tujuan Business Plan__44 

G. Terms of reference (TOR)_ 45
H. Perencanaan Keuangan__46
I. Time Schedule_49
J. Contingency Plan_ 51
K. Soal-soal__51

\section{BAB III Pohon Keputusan}
A. Pohon Keputusan (PK)_ 52
B. Prosedur Dan Tahap Pembuatan PK_ 53
C. PK dan Pengambilan Keputusan_ 54
D. Contoh Soal PK_ 57
E. Perilaku Pengabaian Terhadap Sinyal Kegagalan_65
F. Faktor Penyebab Perilaku Pengabaian
68
G. Soal-soal__73

\section{BAB IV Teknik Pengambilan Keputusan secara Sederhana}
A. Analisis Perbandingan Sepasang_ 75
B. Analisis Jaringan__ 76
C. Teknik Implikasi Plus Minus_79
D. Analisis Kekuatan Lapangan_ 81
E. Analisis Biaya Dan Manfaat__86
F. Analisis Regresi dan Korelasi__88
G. Analisis Forecasting Moving Average__100
H. Soal-soal_103 


\section{Konsep Dasar}

\section{Pengambilan Keputusan}

\section{A. Definisi keputusan}

Manusia akan berhadapan dengan permasalahan. Dalam perspektif ekonomi; pada penciptaan Tujuan, Visi, Misi organisasi ekonomi, manusia selalu berhadapan dengan masalah mengenai "why, who, how, what, \& when", serta pertanyaan stereotip lain. Pertanyaan yang muncul menyiratkan kehadiran permasalahan yang harus dipecahkan, bila si pengambik keputusan hendak mewujudkan tujuan, baik jangka pendek maupun jangka panjang, organisasi.

Dalam prosedur pemecahan permasalahan, individu akan memiliki beberapa alternatif yang bisa dipilih. Tetapi perlu diingat bahwa setiap alternatif akan memiliki dampaknya masing masing. Seorang individu juga diasumsikan bahwa ia akan memilih sebuah keputusan agar dapat memaksimalkan kepuasan pada pemenuhan keinginan secara rasional.

Mahluk yang rasional "terpaksa" mengambil keputusan yang dapat memaksimumkan hasill karena didorong atas alasan mengenai ketersediaan sumber daya yang terbatas. Teori kelangkaan (constraints / scarcity) akan memaksa individu untuk 
menyeimbangkan perspektif antara perumusan keputusan rasional berhadapan pada pengambilan langkah yang akan memberikan manfaat optimal.

Berdasarkan keseimbangan perspektif itulah, maka lahirlah model dan teori pengambilan keputusan.

Desicion making (pengambilan keputusan) adalah sebuah mekanisme dalam melakukan penilaian dan menyeleksi sebuah / beberapa pilihan. Ketetapan desicion making dirumuskan setelah menjalani beberapa proses perhitungan rasional dan peninjauan alternatif. Sebelum kesimpulan dirumuskan dan dilaksanakan, terdapat beberapa jenjang tahapan yang harus dilalui oleh si pembuat keputusan. Jenjang tahapan tersebut mungkin dapat meliputi rekognisi permasalahan dasar, meniapkan putusan alternatif yang dapat dipilih, lalu mencapai fase pemilihan keputusan terbaik.

\section{B. Tahap Pengambilan Keputusan}

Teori dari Simon (1960) menyebutkan beberapa jenjang pengambilan keputusan, olehnya dinyatakan 4 tahap yaitu :

1. Intelligence : pengumpulan data dan informasi untuk identifikasi masalah.

2. Design : tahap perumusan penanggulangan dalam bentuk opsi pemecahan permasalahan. 
3. Choice : fase menyaring keputusan dari solusi alternatif alternatif yang tersedia.

4. Implementation : tahap menjalankan pilihan keputusan dan mengevaluasi hasil.

\section{Proses Pengambilan Keputusan}

Pengambilan keputusan dibuat berdasar proses analisis, pendenahan, dan pensimulasian melalui berbagai perhitungan alternatif solusi yang mungkin dilakukan. Tahap pengambilan keputusan mempunyai beberapa langkah :

Langkah 1

Pemahaman dan menyatakan dasar permasalahan. Para pemimpin sering berhadapan dengan kenyataan bahwa permasalahan yang sulit dipecahkan atau sukar diidentifikasikan, bukan merupakan dasar dari sebuah permasalahan. Para pemimpin dapat memahami masalah yang sedang dihadapi dengan beberapa fase. Pertama, pemimpin secara sistematis menguji hubungan sebab-akibat. Kedua, pemimpin menganalisis perubahan atau penyimpangan normal sebuah permasalahan yang sedang berlangsung.

\section{Langkah 2}

Pencarian dan proses data analisis yang signifikan. Setelah pemimpin menemukan dan menyatakan masalah, pemimpin harus 
memformulasikan langkah kedepan. Langkah pertama pemimpin adalah harus menetapkan data dan informasi apa yang diperlukan dalam merumuskan keputusan yang akurat. Langkah yang kedua adalah memastikan bahwa informasi dan data tersebut mampu didapatkan secara tepat waktu dan relevan.

\section{Langkah 3}

Pegembangan solusi alternatif. Kecenderungan dalam menerima solusi alternatif keputusan yang feasibel akan mampu menghindarkan pemimpin dari kegagalan dalam pencapaian dan penyelesaian yang optimal. ekspansi sejumlah alternatif solusi membuat pemimpin secara otomatis menghalangi kecenderungan dalam pembuatan keputusan yang tergesa-gesa, sekaligus mengarahkan seorang pemimpn untuk merumuskan keputusan yang makin efektif. Pemimpin harus menentukan solusi alternatif yang secara overall mampu menyelesaikan permasalahan, walaupun pilihan tersebut bukanlah hal ideal.

\section{Langkah 4}

Evaluasi alternatif solusi. Setelah pemimpin mengemukakan sekumpulan alternative solusi, pemimpin harus melakukan evaluasi sekumpulan alternatif tersebuti. Tujuan dari evaluasi adalah untuk menilai tingkat efektifitas dari setiap alternative solusi. 
Langkah 5

Pemilihan alternatif solusi terbaik. Pengambila keputusan adalah hasil pengevaluasian berbagai alternatif yang tersedia. Alternatif yang terpilih harus didasarkan pada kemampuan pemimpin dalam menghadapi konsekwensi yang akan terjadi setelah implementasi dari alternatif terpilih tersebut.

\section{Langkah 6}

Implementasi Keputusan. Setelah solusi terbaik terpilih, para pemimpin harus menetapkan perencanaan untuk menghadapi berbagai potensi permasalahan yang mungkin timbul dalam pelaksanaan keputusan. Sejalan dengan itu, pemimpin perlu memperhitungkan berbagai ketidakpastian dan bahaya sebagai konsekuensi dalam sebuah keputusan. Pada langkah ini, keputusan pemimpin juga harus mensyaratkan prosedur pelaporan kemajuaan secara periodik serta menyusun tindakan preventif apabila timbul penyimpanggan dari implementasi keputusan.

\section{Langkah 7}

Evaluasi perolehan keputusan. Implementasi evaluasi keputusan harus diawasi secara periodik. pemimpin akan melakukan penilaian apakah implementasi telah dilakukan secara baik dan keputusan membuahkan hasil yang ditargetkan. 


\section{Tujuan Dan Asumsi Pengambilan Keputusan}

Tujuan terwujudnya perspektif pengambilan keputusan ialah mendukung pembangunan sebuah kondisi yang mampu memaksimumkan harapan. Jika kejadian yang diharapkan belum / tidak terwujud, maka muncullah masalah atau resiko. Teori pengambilan keputusan mencoba untuk meminimasi resiko yang mungkin muncul, dimana kelak harus dihadapi oleh pemimpin yang merumuskan keputusan.

Asumsi disusun untuk penyederhaan kerumitan dalam teori dan model yang digunakan. Jika pemimpin ingin merepresentasikan hal yang eksplisit dalam definisi permasalahan, maka syarat asumsi harus terpenuhi sebagai "tolak ukur" dalam mewujudkan pemaksimalan kepuasan dan harapan, sekaligus untuk meminimasi resiko.

Dalam mengambil sebuah keputusan, ditemukan sejumlah asumsi yang patut dipenuhi agar implementasi keputusan memberikan dampak yang diinginkan:

1. Keputusan wajib diambil dengan rasional!

2. Keputusan diimplementasikan untuk pengoptimalan hasil.

3. Keputusan berawal dari definisi dan menyatakan masalah.

4. Pengambilan keputusan merumuskan sebuah target yang lengkap. 
5. Pencarian data dan informasi yang relevan dalam usaha menghasilkan beberapa kriteria.

6. Kriteria yang dirumuskan dipergunakan dalam melahirkan beberapa solusi alternatif

7. Menimbang kecocokan setiap kriteria bersama setiap solusi alternatif

8. skoring untuk setiap alternatif solusi

9. memilih solusi alternatif dengan skor terbesar

10. Keputusan dihasilkan melalui mekanisme yang sistematis

\section{E. Konsep Pengambilan Keputusan}

Ilmu pengambilan keputusan adalah sebuah filosofi dan metode analisis yang bersinggungan dengan sejumlah penyatuan pemikiran berbeda, yang disimpulkan secara ilmiah dan sistematis, diperuntukkan untuk membantu pengambil keputusan dalam memilah satu solusi terbaik dari sejumlah solusi alternatif yang tersedia dimana akan mengarahkan pada hasil peristiwa yang mungkin bisa berbeda.

Ilmu pengambilan keputusan bisa diterapkan dalam kondisi kepastian, ketidakpastian, atau beresiko.

Keputusan pada kondisi kepastian menggambarkan bahwa setiap solusi keputusan yang dirumuskan akan mengarah hanya pada sebuah konsekwensi. Keputusan pada kondisi kepastian memiliki 
atribut yang sederhana, menggambarkan rangkaian yang teratur dan eksplisit dari konsekwensi. Pengambil keputusan / pemimpin umumnyanya akan mengambil alternatif solusi yang mengandung nilai manfaat yang paling besar tanpa harus menimbang konsekwensi yang mungkin terjadi.

Pada kondisi ketidakpastian atau / dan beresiko, ilmu pengambilan keputusan menyajikan dua pendekatan strategi.

Strategi pertama disebut game theory, dimana strategi ini akan mengeksploitasi lebih dalam mengenai kriteria solusi yang diupayakan dalam perspektif yang lebih lebar dengan menggunakan asumsi teori permainan ( $\max$ - min rule) dalam Linier Programming, Assignment Method, Transportation Method, dll.

Strategi kedua adalah menanggulangi atau mengeliminasi prosentase ketidakpastian sehingga pengambilan keputusan akan menghasilkan bahaya yang lebih moderat dengan mengembangkan penilaian tingkat probabilitas secara subyektif.

Dari penjelasan sebelumnya, dapat kita simpulkan beberapa kriteria dasar yang melandasi ilmu dan metode pengambilan keputusan. Kriteria dasar tersebut adalah: 


\section{Decision Maker}

Pada kamus Bahasa Indonesia, definsi dari Decision Maker ialah perumus atau pembuat atau pengambil keputusan. Decision Maker adalah pihak yang memiliki wewenang dalam merumuskan dan menentukan pillihan final dari beberapa solusi alternatif. Umumnya wewenang ini dimiliki oleh personil setingkat manajer / pemimpin. Decision Maker harus berperilaku atas kesadaran rasional dalam memilih sebuah alternatif, serta bersiap untuk menanggung akibat yang timbul dalam implementasi alternatif tersebut.

\section{Objective}

Dalam ilmu pengambilan keputusan, sasaran merupakan hal yang ingin dicapai atau diraih oleh si pembuat keputusan. Sasaran dapat dipecah dalam kategori kriteria: umum, spesifik, abstrak, kurang penting, penting, dll. Seorang pemimpin bisa saja mempunyai beberapa tujuan sekaligus (multiple objectives).

\section{Constraints}

Dalam mewujudkan tujuan, sang pembuatan keputusan akan berhadapan dengan beberapa pembatas. Batasan adalah sejumlah faktor peristiwa yang bermula pada lingkungan intenal dan eksternal, yang menghambat individu dalam melaksanakan implementasi. Variabel ini mencerminkan bahwa sejumlah sasaran yang ingin diwujudkan bisa saja tidak tercapai. 


\section{Uncertainty}

Masa depan dari kegiatan bisnis dipenuhi oleh unsur ketidakpastian. Ketidakpastian adalah peristiwa dimana saat terdapat unknown elemen berada pada satu kategori asumsi. Ilmu pengambilan keputusan memiliki metode untuk meramalkan elemen peristiwa yang berpotensi muncul di masa depan. Saat pengambil keputusan melaksanakan mekanisme pengambilan keputusan secara benar, prosentase ketidakpastian diharap akan berkurang.

5. Risk

Resiko adalah kesenjangan atau gap antara kejadian yang diinginkan terjadi dengan kejadian yang terealisasi. kesenjangan ini merupakan pertanda adanya disparitas atau penyimpangan atas kejadian yang telah direncanakan dengan kejadian yang telah terjadi di lapangan.

\section{Utility}

Nilai kegunaan diperkenalkan di ilmu Ekonomi yang diibaratkan atas kemampuan produk dan jasa dalam memenuhi keinginan manusia. Dalam ilmu pengambilan keputusan, pemimpin harus mengambil alternatif solusi yang memuat nilai kegunaan yang paling besar. Preferensi pemimpin dalam memandang dan mengambil nilai kegunaan akan dipengaruhi oleh sudut pandangnya dalam menghadapi resiko. 


\section{Alternative}

Alternatif adalah sebuah konjungsi tindakan yang memiliki sifat yang dapat saling menggantikan (mutually exclusive) terkait pada peraihan tujuan. Hal ini bermakna jika alternatif A digunakan, dipastikan bahwa alternatif B tidak bisa dipilih.

\section{Consequences}

Konsekuensi / imbas merupakan dampak yang muncul dari beberapa tindakan yang diimplementasi oleh pengambil keputusan. Manfaat adalah imbas positif dihasilkan oleh beberapa tindakan. Semakin tinggi konsekuensi positif didapat, maka semakin rendah konsekuensi negatif (tingkat bahaya, beban biaya, dll) yang akan diterima. Dalam konsep pengambilan keputusan, perangangan pohon keputusan mampu menggambarkan secara mendetail mengenai imbas yang terjadi, baik positif maupun negatif, atas sebuah kejadian.

\section{Criterion}

Kriteria ialah peraturan baku atas pemeringkatan solusi alternatif mengikuti tingkat prioritas pemimpin. Kriteria jua menandakan peletakan urutan dari solusi alternatif yang paling diinginkan. Secara akal sehat, kriteria menunjukan peringkat tindakan yang diperlukan agar implementasi pengambilan keputusan berhasil dengan baik. 
10. Value

Nilai / skor akan dikaitkan dengan besaran pengembalian yang akan diterima. Terdapat korelasi garis lurus terkait konsep optimalisasi dengan skor. Semakin tinggi preferensi atau pandangan pemimpin terhadap sebuah solusi alternatif, maka akan semakin besar harapan / tingkat optimasi atas konsekuensi keberhasilan. skor pada pengambilan keputusan diilustrasikan dalam bagian skala, dipergunakan untuk pengukuran persepsi serta perilaku si pengambil keputusan pada penentuan pemecahan permasalahan dan penetapan alternatif solusi optimal.

\section{Model}

Model adalah sebuah kumpulan proposisi / rumus yang memberikan ilustrasi sederhana mengenai elemen atau aspek peristiwa pada kehidupan bisnis. Model adalah cerminan sederhana mengenai realitas, yang dituangkan dalam bentuk tabel, grafik, atau skema.

Sejumlah model pada ilmu sosial dapat dimanfaatkan dalam membantu mekanisme penentuan solusi alternatif terbaik:

- Model Formal; memperlihatkan hubungan antar sejumlah fenomena yang diobservasi. Cth: tabel \& grafik ekonomi, rumus \& diagram matematis. 
- Model Dinamis; digunakan untuk mengilustrasikan elemen dinamis serta selalu berubah pada sebuah sistem. Misal: variabel penggajian terhadap tingkat produktifitas pegawai.

- Model Korelasional; sebuah model yang mencerminkan hubungan timbal balik antar kejadian yang dicermati, dimana sebuah elemen yang diberikan skor secara tegas akan sanggup mempengaruhi elemen lain dalam sistem.

- Model Peramalan; dipergunakan dalam peramalan peristiwa yang diinginkan akan terjadi di kedepan. Pendekatan statistik dan matematik digunakan sebagai pondasi dalam model forecasting. DII.

\section{F. Masalah pengambilan keputusan}

Ilmu pengambilan keputusan umumnya disangkutkan dengan pemecahan masalah dan pencapaian sasaran / tujuan. Sasaran yang hendak diraih oleh perusahaan memunculkan pertanyaan: "why, who, how, what, \& when". Bila pertanyaan ini mengemuka, maka permasalahan pun akan mencuat. Dengan begitu, dapat disimpulkan bahwa teori pengambilan keputusan dipandang sebagai mekanisme yang runtut dan rasional dalam pemecahan masalah.

Bobot permasalahan akan dinilai berbeda oleh masing masing pengambil keputusan melalui persepsi individual dan gaya 
pemikirannya. Secara lugas, dapat disimpulkan bahwa ilmu pengambilan keputusan akan menyesuaikan dengan tipe permasalahan yang muncul, dan jenis pemecahan masalah akan diambil dengan tipe pendekatan yang bervariasi dari setiap individu.

Tipe permasalahan dapat dipecah menjadi 2 kategori, kategori masalah terikat, serta kategori masalah tidak terikat. Kategori masalah terikat adalah permasalahan yang mungkin lebih sederhana untuk didefinisikan serta sangat mungkin dipecahkan secara baik, tepat, serta akurat baik melalui bantuan aplikasi atau dengan menganalisis data masa terdahulu. Di lain sisi, masalah tak terikat merupakan masalah yang tingkat ambiguitasnya tinggi, sangat sulit didefinisikan secara jelas, dan perlu usaha ekstra untuk memahaminya dengan benar meski Anda memiliki basis data masa lalu yang berguna sebagai landasan pemikiran.

\section{G. Perubahan Lingkungan Yang Mengakibatkan Perubahan Keputusan}

Kerumitan apakah yang dihadapi dalam pengambilan keputusan?

Seiring berkembangnya teknologi informasi yang menyebabkan perubahan dalam lingkungan bisnis menjadi tak dapat diprediksi dan semakin liar. Kemelut dalam pengambilan keputusan sudah tidak dapat lagi dihadapi dengan menggunakan metode yang tradisional. 
Solusi teratas dalam tantangan dan masalah hanya mampu diwujudkan melalui penggunaan ilmu pengetahuan selaku peralatan terbaik yang menunjang kita dalam merumuskan alternatif solusi.

Setelah ini, penulis akan menjelaskan beberapa komponen stratejik yang mengharuskan para pengambil keputusan untuk mampu menggunakan aspek kognitif (pengetahuan) pada usahanya untuk mengolah informasi juga ilmu pengetahuan agar mereka mampu meningkatkan prosentase kesuksesan organisasi:

Terdapat sejumlah variabel yang perlu dipertimbangkan pada seluruh pengambilan keputusan.

1. Seiring perkembangan teknologi, Ilmu pengetahuan pun berkembang secara pesat.

2. Persaingan dalam ruang global semakin padat.

3. Semakin handalnya model dan teori yang memberikan hasil strategis maupun taktis.

4. Keikutsertaan pemerintah semakin tinggi dalam mengatur penerapan Business Corporate Social Responsibility.

5. Kemajuan komputer dan internet mendorong organisasi bisnis berkompetisi ke dunia maya. 
6. Semakin tingginya tuntutan para stakeholder untuk dapat campur tangan pada pengambilan keputusan organisasi.

7. Setiap entitas bisnis mampu bergerak secara otonomi sesuai dengan kemahiran pemrosesan ilmu pengetahuan dan informasi.

8. Teknik korespondensi dan penilaian dalam kaidah penelitian alamiah beranjak pesat sehingga dapat dikerjakan dengan computer secara cepat dan akurat.

9. Permasalahan manajerial yang sulit dapat dipecahkan secara sekejap melalui dukungan teknologi informasi.

10. Organisasi berubah semakin efisien dan ramping.

\section{H. Dukungan Sistem Informasi}

Data dan informasi adalah bahan baku utama pada mekanisme pengambilan keputusan. Kealphaan kehadiran informasi akan berakibat sulitnya merumuskan keputusan yang memiliki nilai ekonomis. bahkan pada titik ekstrim, pengambil keputusan tidak akan mampu melaksanakan mekanisme pengambilan keputusan saat informasi tidak tersedia.

Pendayagunaan teknologi informasi mutakhir bisa mendukung Anda dalam memperoleh, mengolah, dan mendistribusikan pengetahuan dan informasi ke seluruh sudut organisasi. Karakteristik 
unggul pada sistem informasi merupakan penerapan perangkat komputer yang terhubung secara luas, seperti intranet dan internet. Selain itu, melalui sistem informasi, individu bisa memperoleh dan mendistribusikan informasi dengan nilai perolehan ekonomis yang besar.

Perbedaan pada pengambilan keputusan sejatinya diklasifikasikan dalam tingkat organisasi, yang berkaitan dengan tingkatan operasional, stratejik, manajerial, dan pengetahuan.

Pengambilan keputusan pada level operasional mengarahkan bagaimana kiat terbaik saat penyelesaian tugas, penilaian kriteria penyelesaian kerja, serta evaluasi dan umpan balik hasil pencapaian keputusan yang diimplementasi. Pengambilan keputusan level stratejik berhubungan dengan perumusan beberapa sasaran, sumber daya, serta kebijakan dalam organisasi saat mengantisipasi penyimpangan yang muncul. Pengambilan keputusan level manajerial secara filosofis bersilangan dengan pemanfaatan sumber daya milik organisasi untuk dimanfaatkan secara efisien dan efektif. Pengambilan keputusan jenjang pengetahuan berkaitan dengan peninjauan ulang sejumlah gagasan baru untuk menciptakan jasa dan produk, serta mekanisme dalam pendistribusian informasi pada sistem organisasi. 


\section{Gaya Pemikiran \& Persepsi}

Jantung pada mekanisme pengambilan keputusan ialah gaya pemikiran dan persepsi. Cara berpikir seseorang mengenai lingkungan dan objek di sekelilingnya, akan membentuk bagaimana cara seorang individu mempertanyakan sebuah hal, serta bagaimana ia membentuk respon atas permasalahan yang ada di depannya.

Diagram dibawah menunjukan klasifikasi gaya pemikiran berasal dari perspektif scientifica :

Gambar 1.1 gaya pemikiran

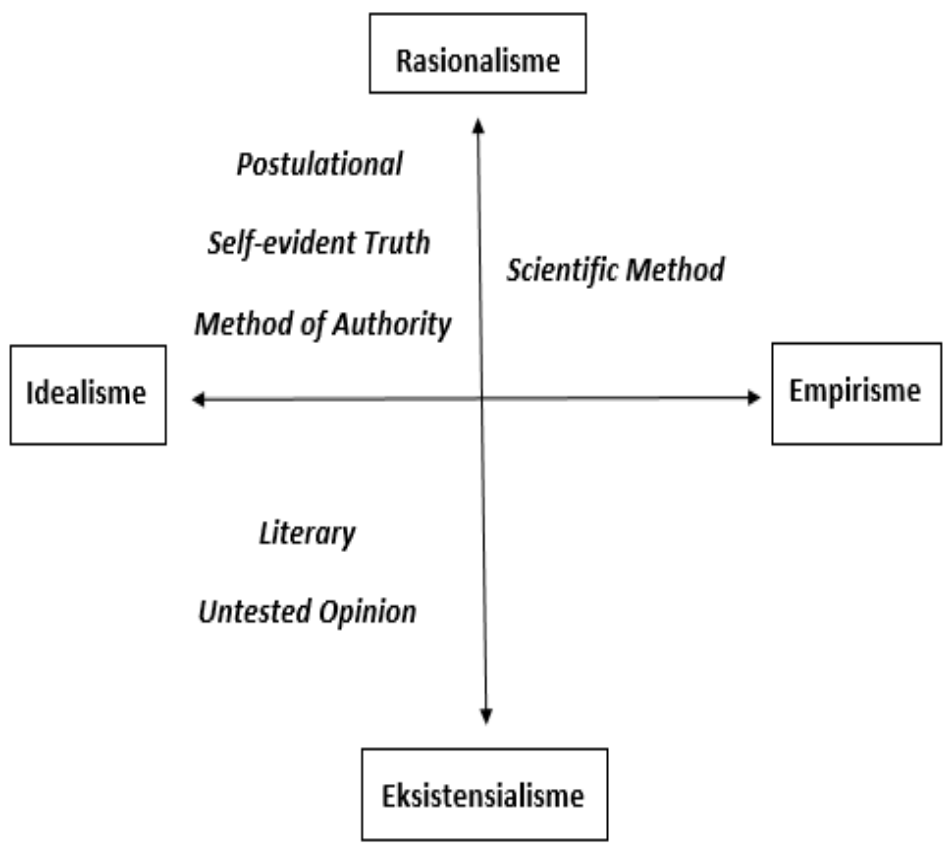


Gaya Pemikiran: klasifikasi Rasionalisme - Idealisme

Gaya pemikiran postulational adalah gaya berpikir berdasar pada pembuatan teknik simulasi dan model matemati. manfaat utamanya digunakan dalam mereduksi beberapa peluang terjadinya insiden yang negatif.

Gaya pemikiran self evident truth diketahui sebagai sebuah metode untuk mengetahui informasi melalui penilaian definisi kebenaran bergaya subyektif. Metode ini dianggap kurang akurat karena lingkungan bisnis berisi variabel keberagaman juga bersifat dinamis yang tak bisa diacuhkan.

Gaya pemikiran method of authority merupakan sesuatu yang diyakini kebenarannya melalui rujukan pada quotes individu yang memiliki keahlian atau memiliki yurisdiksi.

Gaya Pemikiran: klasifikasi Idealisme - Eksistensialisme

Gaya pemikiran literary dinyatakan sebagai pola berpikir yang berlandaskan ilmu pengetahuan, akan tetapi mengacuhkan sistematika dan mekanisme pengambilan keputusan. Dalam pola ini, pengambil keputusan menimbang pemecahan permasalahan yang dilakukan oleh organisasi sejenis dalam penapcapaian tujuannya, yang kemudian strategi tersebut akan diadopsi di dalam mekanisme pengambilan keputusan pada organisasinya. 
Gaya pemikiran untested opinion adalah gaya pengambilan keputusan yang mendorong si pembuat keputusan mengambil sebuah keputusan dalam sebuah organisasi tanpa melihat secara jelas nilai kebenaran dari pernyataan dan informasi yang diajukan. Gaya ini sangat beresiko karena setiap permasalahan skala besar yang muncul memiliki keunikan tersendiri serta membutuhkan penyelesaian secara khusus.

Gaya Pemikiran: klasifikasi Rasionalisme - Empirisme

Gaya pemikiran scientific method dijadikan acuan pertama pada pengambilan keputusan modern. Gaya ini berciri:

1. Observasi langsung pada fenomena dan permasalahan

2. Secara eksplisit mendefinisi variable dan mekanisme yang digunakan untuk perolehan data empirik

3. Pengusulan hipotesis yang terukur dan dapat diuji

4. Tata cara perumusan hipotesis yang unggul

5. Penggunaan alat uji hipotesis dan alat ukur berdasar statistika dan bukan pada dasar pengalaman

6. Proses swa-pembenaran (saat hipotesis melenceng, margin error kurang dari 5\%)

Pemikiran gaya ini menggabungkan akal sehat dengan observasi empirik untuk mendapatkan sebuah pemecahan masalah melewati pengumpulan informasi yang bernilai dan relevan. 


\section{J. Model Pengambilan Keputusan Yang Tak Terstruktur}

The Garbage Can Model (model tong sampah) adalah model khusus yang diperuntukkan dalam kaidah model rasional dibatasi dalam menghadapi permasalahan yang tak terstruktur.

Model tong sampah memutarbalikkan langkah awal pengambilan keputusan. Seperti yang kita pelajari diatas, penentuan solusi baru dirumuskan untuk pemecahan masalah. Dalam metode ini, penentuan solusi telah dilakukan sebelum masalah tersebut muncul ke permukaan. Sesuai dengan konsep pengambilan keputusan tak terstruktur, Anda dapat mengambil sebuah pemecahan permasalahan yang dapat diselesaikan melalui solusi yang tersedia.

Alur dari Garbage Can Model adalah:

define what we have now $\rightarrow>$ problems

in the future $\rightarrow$ potential solution

\section{K. Pengambilan Keputusan Secara Berkelompok}

Pengambilan keputusan ala berkelompok pada intinya tidak jauh terpaut dengan pengambilan keputusan perorangan, perbedaannya terletak pada penetapan langkah strategis untuk menghadapi uncertainty. 
Beberapa gagasan ahli mengatakan jika pengambilan keputusan secara berkelompok mampu menghasilkan nilai kesimpulan yang lebih tinggi, karena kesimpulan yang diperoleh tidak mengandung bias subyektifitas, walau perolehan hasil mungkin tidak melambangkan keputusan yang ideal.

Kelebihannya, karena dihasilkan oleh seluruh konstituen kelompok, maka keputusan final bisa lebih mudah dirumuskan dan dieksekusi. Kekurangannya, mekanisme pengambilan keputusan berpotensi mengkonsumsi waktu yang cukup lama, juga terdapat probabilitas yang besar munculnya keterikatan buta dalam pemikiran kelompok.

Ketika para pemimpin terkekang pada kelompok, pada umumnya mereka pun juga terikat dengan pemikiran kelompok. Keterkekangan ini acapkali menyebabkan bias dalam pengambilan keputusan, dikarenakan para pemimpin secara simultan terikat dalam sebuah kesimpulan yang tidak berasal dari dasar pengambilan keputusan yang tepat.

Seringkali ditemui, tindakan dan perilaku yang didemonstrasikan oleh konstituen kelompok selalu mengarah pada pemastian keberhasilan visi dan misi kelompok. karena semua tindakan dipusatkan supaya tujuan kelompok tercapai, maka dapat dikatakakan bahwa anggota kelompok akan terikat buta dengan 
sebuah tindakan tertentu (yaitu tindakan yang menguntungkan kelompok dan disetujui oleh sebagian besar anggota kelompok) tanpa menimbang tindakan obyektif demi kepentingan organisasi secara umum.

Pemikiran secara kelompok pun berpotensi menghasilkan resiko lanjutan, yaitu munculnya kemungkinan kelompok yang kuat menindas kelompok minoritas. Dalam etika dan tata cara pengambilan keputusan, gerakan menekan minoritas yang dilakukan oleh mayoritas pada organisasi akan menimbulkan eskalasi konflik serta kegagalan sistemik pada organisasi.

Kehadiran pemikiran secara berkelompok, walau memiliki beberapa manfaat, tetapi metode itu juga beresiko tinggi. Dalam menanggulangi resiko pada kelemahan pengambilan keputusan secara berkelompok, para ahli mengajukan tiga cara: Delphi technique, brainstorming technique, dan the nominal group technique.

\section{Pengambilan keputusan dalam kondisi yang pasti dan tidak pasti}

Para pengambil keputusan akan selalu diminta untuk menunjukan performa terbaik dalam perumusan keputusan. Tapi lebih dari iru, pengambil keputusan juga dituntut agar mereka juga 
mampu membuat keputusan sebelum permasalahan timbul ke permukaan.

Bila pengambilan keputusan baru dirumuskan karena terdapat masalah yang timbul, dikatakan bawa sesungguhnya kita belum bisa merumuskan keputusan yang terbaik. Membahas, mencari serta mengambil keputusan sebelum masalah datang mengetuk, adalah ciri utama atas para pemimpin yang visioner (Robbins, 2001).

Dalam pengambilan keputusan, seorang pemimpin akan dipengaruhi oleh 3 "zona waktu": masa lalu, masa kini, dan masa depan.

Tabel 1.1 zona waktu pengambilan keputusan

\begin{tabular}{|c|c|c|}
\hline No & $\begin{array}{l}\text { Landasan } \\
\text { Waktu }\end{array}$ & Deskripsi \\
\hline 1. & Masa Lalu & $\begin{array}{l}\text { - } \quad \text { Pengalaman \& peristiwa masa dahulu } \\
\text { - } \quad \text { rencana masa lalu yang tidak terwujud } \\
\text { secara sempurna terselesaikan } \\
\text { - } \quad \text { Ketersediaan informasi dari masa lalu }\end{array}$ \\
\hline 2. & Masa Kini & $\begin{array}{l}\text { - Perubahan lingkungan: ekonomi, } \\
\text { sosial budaya, politik }\end{array}$ \\
\hline
\end{tabular}




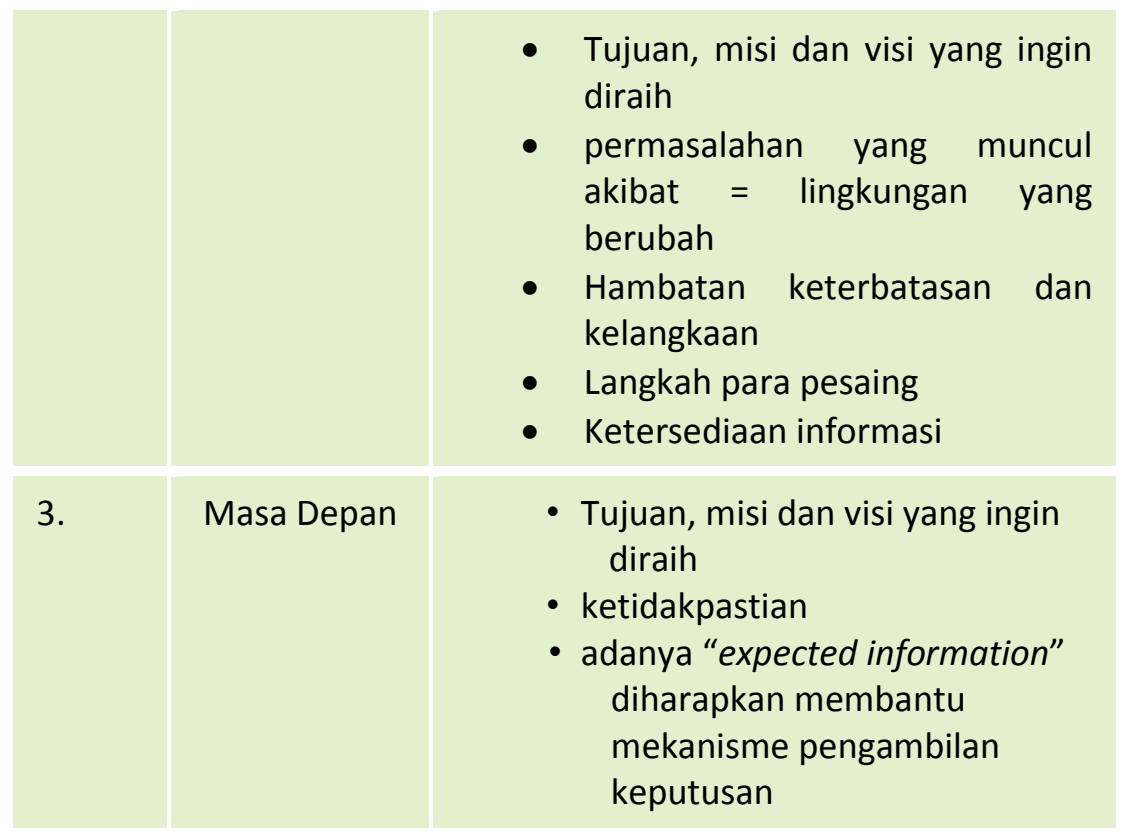

Peran pengambil keputusan visioner adalah bertindak untuk beradaptasi dan mengantisipasi transisi lingkungan yang bergerak cepat. Semua daya dan upaya akan mereka kerahkan dalam menyiapkan organisasi untuk merespon tantangan yang bisa saja datang secara tiba tiba.

Dengan demikian, mekanisme pengambilan keputusan yang dilakukan manajer visioner tak hanya reaktif, tapi juga bersifat keputusan yang cenderung direncanakan untuk mengendalikan dan membaca lingkungan perusahaan. 
"Siapkah Anda menjadi pengambil keputusan yang visioner?"

\section{Soal Soal}

1. Sebutkan dan jelaskan mengenai tahapan dalam pengambilan keputusan!

2. Jelaskan mengenai variabel yang dipertimbangkan manager dalam setiap pengambilan keputusan!

3. Gaya pemikiran jenis apa yang digunakan sebagai landasan ilmu pengambilan keputusan? Jelaskan!

4. Apakah pengambilan keputusan berkelompok dapat diklasifikasikan sebagai pengambilan keputusan yang berbahaya? Jelaskan!

5. Jelaskan mengenai 3 zona waktu pengambilan keputusan manager! 


\section{Business Plan dan Etika dalam Pengambilan Keputusan}

\section{A. Pertimbangan Etika, Tanggung Jawab Sosial, Dan Pandangan Tentang Rasional Ekonomi}

Etika merupakan bidang Ilmu yang membedah perbuatan benar dan perbuatan salah manusia sepanjang yang dapat dimengerti oleh alam sadar manusia.

Seorang pemimpin diwajibkan mengikutsertakan etika pada proses pengambilan keputusannya, sebab faktor utama yang berlaku pada masyarakat dunia saat menilai sebuah unit bisnis yang berkualitas ialah pandangan dan implementasi terhadap etika.

Prinsip organisasi terhadap perwujudan etika dalam proses pengambilan keputusan membentuk perwujudan nyata melewati sejumlah model ekonomi serta manajemen kontemporer, yaitu; environmentally - friendly economic activities, business ethics, green product, dll.

rancangan tersebut adalah pengembangan lebih jauh dari rancangan dasar yang menjadi pondasi pendirian organisasi: social responsibility / tanggung jawab sosial. 
Social responsibility mengisyaratkan bahwa pengambil keputusan sudah bersiap dengan pertimbangan konsekuensi dari keputusan yang dilakukan terhadap kesejahteraan paguyuban masyarakat disekitar / local communities responsibillity serta lingkungan alam / environmental responsibility. Misal: perusahaan tak disarankan melakukan kebijakan advertising yang cenderung mengelabui konsumen.

"sebagai manusia yang rasional, saya akan memanfaatkan sumber daya yang tersedia hanya untuk perkembangan dan kesejahteraan internal organisasi saya. Saya tidak Ingin membuang sumber daya saya yang berharga untuk sesuatu yang tidak rasional seperti tanggung jawab sosial"

Pertimbangan etika memang sewajarnya menjadi sebuah prinsip dasar bagi seluruh entitas bisnis dan dasar dari pengambilan keputusan pada setiap aktifitas. Perwujudan etika, pada jangka panjang, dapat membantu pertumbuhan usaha dan pertumbuha organisasi di masa mendatang. 
Perilaku rasional dijelaskan umpama perilaku pemenuhan keperluan ekonomis yang dihasilkan oleh pandangan egoistis. Mengikutsertakan kebutuhan individu lain, mengandung siratan pembatasan pada pemenuhan keinginan individu.

Dalam perspektif ekonomi pun, pertanggungjawaban sosial individu terhadap masyarakat adalah menghasilkan keuntungan dan kemakmuran bagi diri, dimana tindakan tersebut pada akhirnya akan menghasilkan kemakmuran bagi masyarakat.

Oleh kenyataan tersebut, banyak pengambil keputusan yang mengesampingkan pertimbangan moral / akhlak / etika dalam mencapai tujuan. Hal ini tidak dapat dibenarkan karena dalam pandangan ilmu agama Islam dan ilmu sosial, seorang individu selain merupakan ekonomis rasional, ia juga harus menjadi manusia yang bermanfaat bagi orang lain (beretika dalam melakukan kegiatan ekonomi). 


\section{B. Pertimbangan Etika Dan Perilaku Organisasi}

Semenjak pemimpin merancang pengambilan keputusan pada lingkup organisasional, maka pembahasan mengenai ilmu pengambilan keputusan tak akan sempurna tanpa telaah etika pada ruang perilaku organisasi.

Ilmu etika adalah sebuah kajian mengenai batasan moral tentang sebuah tindakan, solusi, pemilihan, dan konsekuensi. Maka dari itu, pemimpin akan memerlukan kerangka berpikir imajiner guna memahami tata cara pembuatan keputusan yang mengandung etika.

Gambar 2.1 kerangka berpikir

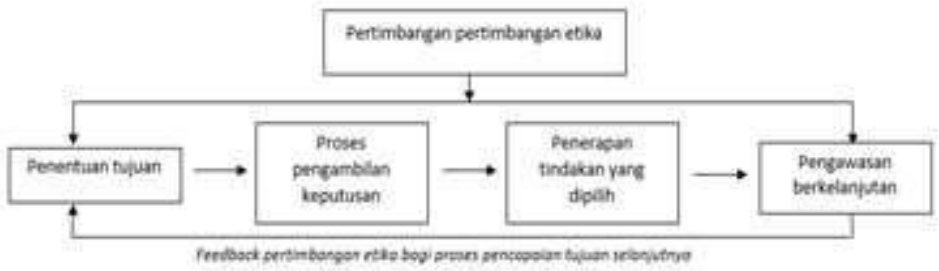

Opsi dalam penggunaan etika selalu tersedia pada setiap mekanisme pengambilan keputusan, baik pada keputusan rasional, pada keputusan rasional yang dibatasi, bahkan pada keputusan secara berkelompok. 
Supaya tiba pada jenjang penerapan moralitas pada pengambilan keputusan, pemimpin perlu mengetahui faktor yang mengilhami perilaku beretika juga perilaku tak beretika.

Disebutkan bahwa terdapat faktor eksternal dan faktor internal yang mengilhami pengambilan keputusan pada organisasi. Rerangka berpikir yang berperan dalam pemahaman tindakan etis / tak etis bisa dilihat pada bagan berikut:

Gambar 2.2 faktor yang mempengaruhi etika

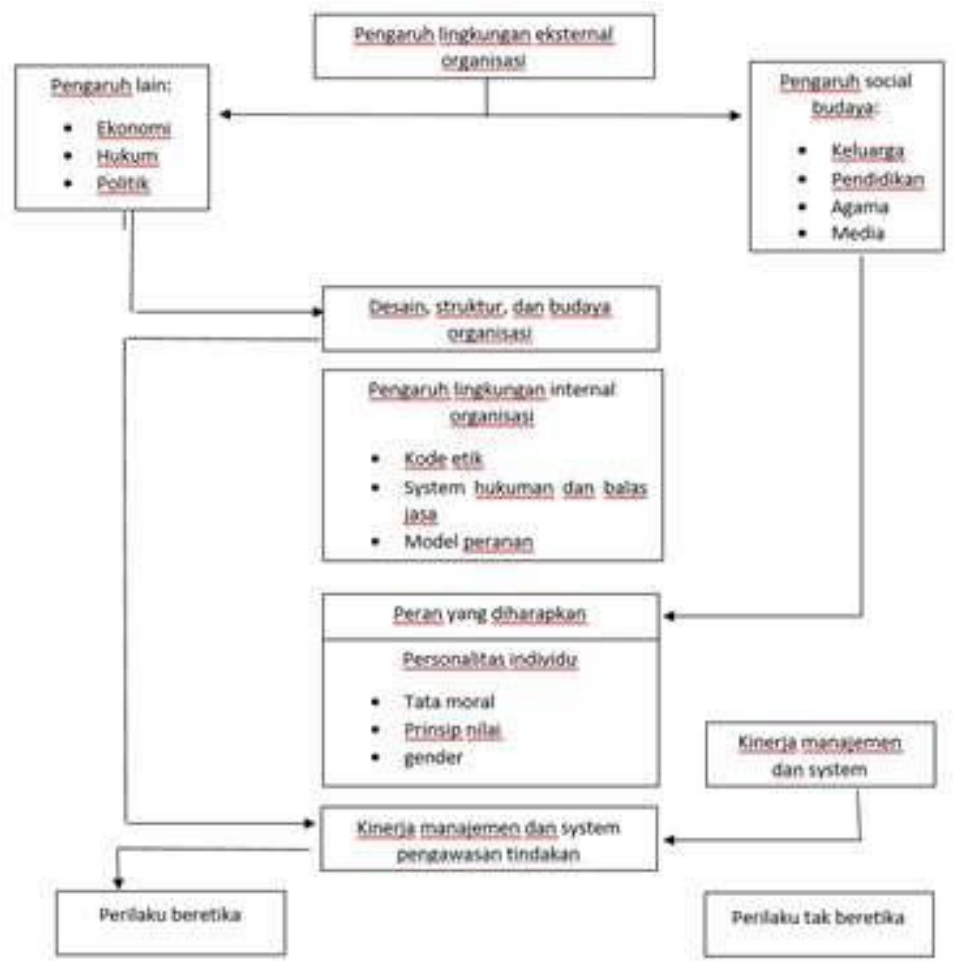


Kekuatan lingkungan eksternal lainnya semacam perubahan iklim ekonomi, politik, dan hukum mempengaruhi budaya organisasi, desain, dan struktur. Selanjutnya budaya organisasi, desain, dan struktur pada akhirnya juga mempengaruhi kondisi internal organisasi.

Variabel dominan dalam organisasi internal pada pengambilan keputusan ialah budaya organisasi. Organization culture adalah seperangkat praktik norma yang diikuti oleh segenap anggota organisasi berhubungan dengan pandangan tentang bagaimana sebuah fenomena terjadi di dunia.

Semenjak individu merupakan pelaku pengambil keputusan yang akan dipengaruhi oleh faktor internal dan eksternal dalam memformulasikan keputusannya, organisasi harus membangun bentuk pengawasan tingkah laku yang baik.

Struktur pengawasan tingkah laku yang baik bisa mendorong tumbuhnya kinerja manajerial yang lebih berkualitas. Tujuan finalnya adalah membantu terkonstruksinya tingkah laku yang beretika, khusunya dalam proses pengambilan keputusan organisasi.

Faktor eksternal lain (sosial budaya) dimana mempengaruhi perilaku, adalah agama, media, pendidikan, dan keluarga. Faktor ini secara tidak langsung mempengaruhi tingkah laku, 
tetapi akan mendominasi persepsi dan gaya pemikiran si pengambil keputusan terhadap prinsip moral dan tata nilai.

apabila tata nilai / budaya yang terbangun bertumpu pada kebiasaan aktivitas yang baik, akan terbentuklah pola pikir mengenai pengelolaan organisasi yang baik jua. Budaya organisasi berpengaruh langsung membentuk pola pengambilan keputusan seseorang dalam organisasi.

Akibat dari lingkungan eksternal hal sosial budaya akan menghasilkan personalitas seseorang yang unik dalam setiap pengambilan keputusan. Form (1997) menyatakan, keunikan tersebut mampu diidentifikasi kedalam 5 jenis pengambil keputusan pada organisasi:

Jenis ketergantungan, adalah tipe perumus keputusan yang memiliki kepercayaan diri yang rendah, dan acapkali melibatkan individu lain dalam pencarian solusi. Bahkan keputusan yang dia ambil bisa berubah total jika terdapat pihak asing yang dapat mempengaruhi pemikirannya.

Jenis eksploitatif, adalah tipe yang cenderung mengeksploitasi pihak lain / bawahan untuk pemenuhan kebutuhannya sendiri. Pengambil keputusan bertipe ini kurang mampu memahami permasalahan secara mendetail, tetapi ia menuntut pendapat dari berbagai pihak, terutama 
bawahannya. Pendapat itu selanjutnya ia ambil dan diklaim sebagai gagasan dan pemikirannya.

Jenis tabungan, adalah tipe pengambil keputusan yang condong bersikap dan berpikir picik serta memiliki egoisme tinggi. Hal ini terlihat saat dia selalu berupaya meningkatkan awareness yang dimilikinya serta tidak berkeinginan untuk membagi keahlian yang ia miliki pada orang lain.

Jenis pemasaran, adalah tipe pengambil keputusan yang sering menjalankan konsep advertising. dia kerap mengiklankan kemampuan dan kekuasaannya pada berbagai pihak, khususnya atasan dan bawahannya, saat ia memiliki kesempatan. Jenis ini biasanya terbuka terhadap gagasan pihak lain, tapi dia akan lebih tangguh dalam mempertahankan gagasannya agar ia memperoleh citra yang lebih unggul dari manusia di sekelilingnya.

Jenis produktif, adalah tipe perumus keputusan yang mepunyai semangat kerja yang tinggi, serta setiap gagasan pemikirannya cenderung mengarah pada visi yang jauh kedepan. Dia sangat mengagungkan konsep cooperative terhadap berbagai pihak, terutama kalangan internal organisasi. 


\section{Kriteria Etika Dalam Pengambilan Keputusan}

Pengaruh penting dari penerapan etika terhadap pengambilan keputusan ialah efek postif dari reputasi organisasi (good will). Organisasi yang menerapkan etika pada landasan kegiatan yang positif akan dipandang secara positif oleh rekanan bisnis dan konsumen.

Good will merupakan harta organisasi yang paling berharga dalam jangka panjang. Good will terkonfigurasi dari akumulasi implementasi etika dalam periode waktu tertentu. Ketika sebagian kecil organisasi tidak mampu menerapkan perilaku etis, seluruh organisasi bisa merasakan "getahnya".

Perumus keputusan dalam perusahaan mampu menggunakan sejumlah kriterion dalam pengambilan keputusan yang beretika:

1. Paham Manfaat (Utilitarianism)

Kriteria ini berdasarkan hasil atau imbas dari seperangkat keputusan. Mahzab ini menunjukan sebuah keputusan harus diambil untuk menghasilkan manfaat / kebaikan terbesar untuk mayoritas (to provide the greatest good for the majority).

Mahzab ini menggelora dalam banyak pikiran pengambil keputusan dalam kegiatan bisnis karena memiliki kesamaan 
dengan tujuan utama yang hendak diperoleh dalam bisnis: laba yang tinggi, efektifitias, efisiensi, kualitas.

Kelebihan: meningkatkan produktifitas dan efisiensi organisasi. Pertimbangan etika diseleraskan terhadap perolehan tujuan.

Kelemahan: implementasi etika pada paham ini hanya bersifat parsial, ditujukan semata pada perolehan tujuan sehingga mengekang hak individu yang berposisi minoritas pada organisasi.

Misal: dengan meningkatkan performa organisasi serta meraih level pengembalian investasi (ROI) sebanyak 21\%, pengambil keputusan mampu menyatakan bahwa perusahaan telah menyediakan manfaat menyeluruh bagi seluruh pihak. Skor ROI akan didistribusikan kepada setiap stakeholder.

\section{Fokus Pemenuhan Hak (Rights)}

Kriterion ini mengejawantahkan etika sebagai tahapan dari pemenuhan hak individu, yaitu hak azasi manusia.

Pandangan ini menyatakan bahwa pengambilan keputusan yang beretika adalah penanda bahwa sebuah implementasi kebijakan harus memberikan ruang bagi perlindungan dan pengahargaan pada hak mendasar individual. Dimana bentuk 
hak tersebut; hak kebebasan pribadi, kebebasan menyatakan pendapat, serta hak memperoleh tempat bekerja yang layak.

Kelebihan: mekanisme pengambilan keputusan menerima pertimbangan etis sehingga memayungi stakeholder dan anggota organisasi dari tindakan yang tidak etis. Kriterion ini konsisten dengan hukum bisnis internasional sehingga perusahaan yang mengimplementasikan kriteria ini bisa mendapatkan nilai tambah dari masyarakat dunia.

Kekurangan: kriterion ini memiliki fokus yang ekstrem terhadap HAM sehingga dapat menjadi pedang ganda yang akan mengurangi tingkat pertumbuhan organisasi di masa depan.

3. Berdasarkan Keadilan (Justice)

Kriteria berpondasi keadilan adalah pengambilan keputusan yang diambil dengan mengutamakan penerapan aturan perusahaan yang tidak memihak pihak tertentu.

Pada pandangan ini, norma pada pengambilan keputusan berfokus pada penentuan posisi objektif yang menghasilkan keseimbangan perolehan resiko dan manfaat secara merata dalam organisasi.

Kelebihan: objektifitas akan melindungi kelompok minoritas. Kriterion ini mendorong penerapan bisnis yang membagikan 
kesejahteraan dan keseimbangan yang merata bagi para stakeholder.

Kekurangan: penerapan kriteria secara berlebihan malah mematikan produktifitas, daya inovasi, dan efisiensi anggota organisasi dikarenakan perasaan yang rancu mengenai konsep sama rata dan sama rasa.

\section{Fokus Pemenuhan Kewajiban (Obligation)}

Kriterion ini menerangkan bahwa perusahaan didirikan bertujuan untuk memenuhi dua sasaran: perolehan tujuan pribadi serta peraiahan tujuan bersama. Pencapaian tujuan bersama akan membentuk corporate responsibility.

Organisasi efektif mampu memastikan kemampuannya dalam perwujudan dua tujuan tersebut. Tanggung jawab perusahaan terhadap masyarakat seharusnya sama urgensinya dengan kepatuhan terhadap pemilik perusahaan. Organisasi yang meremehkan tanggungjawab sosial akan merasakan kerugian hebat pada jangka panjang.

Kelebihan: kriterion ini menanamkan urgensi investasi dalam jangka panjang melalui pelaksanaan tanggung jawab sosial. Melalui kriteria ini, organisasi mampu menciptakan kedekatan emosional bersama konsumen. 
Kelemahan: keterlibatan yang ekstrem terhadap tanggung jawab sosial tanpa disokong oleh budget yang mapan akan menimbulkan ketimpangan di perusahaan.

\section{Pengambilan Keputusan Dalam Kondisi Konflik}

Konflik diartikan sebagai pertentangan persepsi antar individu dalam memandang sebuah peristiwa sehingga menimbulkan persilangan pemikiran dan tindakan.

Lebih jauh, Robbins (2011) menerangkan konflik adalah sebuah proses yang mana A melancarkan muslihat yang disengaja untuk menetralisir tindakan B dalam memperoleh kepentingan dan tujuannya.

sementara Handoko (2008) menyatakan konflik ialah ketidaksesuaian satu atau lebih antara anggota perusahaan yang timbul lantaran terdapat keadaan bahwa mereka diharuskan berbagi atas nilai sumber daya yang terbatas, sementara mereka ingin mewujudkan persepsi dan tujuannya masing masing.

Setiap adanya konflik, pasti mempunyai latar belakang musabab. Secara general, terdapat empat pencetus konflik. 
a) Perebutan tenaga ahli / sumber daya. Awal sebuah pertikaian ditandai dengan terciptanya perselisihan dalam merebut sumber daya perusahaan yang terbatas.

b) Ancaman eksternal. Keadaan eksternal yang tidak bersahabat jelas mempengaruhi kondisi internal. Adanya gangguan dan teror dari pihak asing akan membuat kerisauan pada tempat kerja sehingga berpotensi meningkatkan eskalasi perselisihan.

c) Ego. Manusia akan menganggap dirinya selalu benar juga terbaik, sehingga ia selalu berselisih pendapat dengan manusia lainnya.

d) Perbedaan kepentingan. Menurut Agency Theory yang membahas perselisihan antara pihak bawahan dan atasan, dimana pihak penyelia disebut prinsipal, dan subordinat disebut agen, menjelaskan bahwa agen wajib bekerja dengan maksimal untuk keberhasilan prinsipal. perselisihan timbul saat agen merasa prinsipal terlalu berambisi mewujudkan keinginan mereka tanpa mempedulikan kebutuhan agen.

Menurut Handoko (2008) ada 5 jenis konflik di organisasi:

1) Konflik pada diri Individu, berlangsung saat individu berhadapan dengan ketidakjelasan moral pada pekerjaannya. 
2) Konflik antar individu, sering kali ditimbulkan karena konflik antar kepentingan.

3) Konflik antara kelompok dan individu, berkaitan dengan reaksi individu dalam merespon tekanan kehomogenan yang ditekankan oleh kelompok.

4) Konflik antar departemen / kelompok dalam organisasi, terbentuk karena perebutan sumber daya perusahaan yang terbatas.

5) Konflik antar entitas bisnis, timbul sebagai dampak persaingan ekonomi. perselisihan ini menyebabkan terjadinya inovasi jasa dan produk, perkembangan teknologi, juga pemakaian aset perusahaan yang makin efisien.

Anda sebagai pengambil keputusan akan selalu berhadapan dengan resiko konflik saat mengambil keputusan. Menurut Daft (2012) dalam bukunya "Understanding the Theory \& Design of Organization" , terdapat 3 usaha untuk meresolusi dan menggunakan konflik untuk meningkatkan performa pada sebuah organisasi:

i. Menggunakan negosiasi dan konfrontasi

Cara ini mempertemukan representasi dari kelompok yang terlibat perselisihan serius. Strategi ini memiliki bahaya dimana kontak fisik berpotensi besar terjadi. Tapi, jika pihak yang 
berkonflik dapat meresolusi masalahnya melalui diskusi bersama, pihak yang berselisih tersebut akan mampu saling memahami sehingga kolaborasi pada masa depan dapat terjalin dengan baik

ii. Menjadwalkan konsultasi antarkelompok.

Saat konflik semakin keruh dan berkepanjangan, anggota departemen mencurigai satu sama lain, juga enggan berkolaborasi, maka pemimpin dapat menengahi sebagai pihak netral atau dapat memanggil konsultan dari eksternal organisasi sebagai pihak penengah untuk melancarkan resolusi konflik.

iii. Rotasi karyawan

Rotasi menandakan bahwa karyawan individu dari sebuah departemen dapat dipekerjakan pada departemen lain untuk sementara ataupun secara permanen. Dengan cara ini, individu tersebut diharapkan mampu menjelaskan problematika dan perspektif departemen awalnya pada sejawatnya di departemen baru.

\section{E. Definisi Business Plan}

Business plan merupakan rangka kerja yang mendeskripsikan setiap aktivitas bisnis yang dikerjakan dari awal mula hingga akhir. 
Lebih spesifik, perencanaan bisnis merupakan sebuah dokumen yang mengilustrasikan kemampuan dan keyakinan sebuah bisnis dalam menjual jasa atau produk sehingga menghasilkan keuntungan prima sehingga menarik minat para penyandang dana.

Business plan dirumuskan untuk meruntut seperangkat kejadian yang harus dilakukan saat terdapat peristiwa yang tidak direncanakan terjadi. Dari keterangan tersebut, dapat disimpulkan jika business plan direncanakan dengan berpatokan pada kondisi realistis atau patut untuk diterapkan.

Sebuah perencanaan bisnis yang baik direalisasikan atas hasil diskusi bersama berbagai kelompok yang mempunyai latar belakang disiplin ilmu pengetahuan, dengan maksud agar nilai perancangan business plan memiliki prosentase keberhasilan dan keberlanjutan dalam jangka panjang.

Sebuah telaah yang dilakukan dengan komprehensif dapat menghasilkan ikhtisar secara komprehensif. Perumusan business plan diusahakan untuk dilakukan secara komprehensif sebab menyangkut cetak biru sebuah bisnis, dimana berisi proses pengambilan keputusan operasional, jaringan komunikasi, dan penentuan langkah praktis dalam menyongsong persaingan bisnis. 
Business plan mutlak dibutuhkan untuk digunakan ketika mengatur entitas bisnis yang ada dalam kondisi yang dinamis. Untuk memiliki perencanaan bisnis yang mendukung rencana strategis, business plan harus mencakup:

1. Environment Scanning, pengamatan lingkungan ialah sebuah prosedur di mana perusahaan mengobservasi dunia untuk mengamati transformasi yang sedang terjadi dan berpotensi akan mempengaruhi kondisi internalnya.

2. Market screening, penjaringan pasar ialah sebuah versi peninjauan lingkungan dimana perusahaan mencoba menemukan pasar yang ia inginkan dengan kemampuan internalnya sekaligus juga untuk menghindari pasar yang tidak diinginkan.

\section{F. Tujuan Business plan}

Setiap pelaku bisnis sebaiknya merancang business plan. Terdapat 5 pertimbangan mengapa pengambil keputusan menyiapkan business plan:

1. Business plan adalah blueprint, dan dapat mengarahkan Anda untuk tetap fokus pada misi yang ditetapkan.

2. Merupakan alat untuk pencarian dana 
3. Adalah alat komunikasi guna menggandeng pihak lain; investor, pemasok, dan konsumen, karena business plan akan menampilkan informasi dari tujuan dan langkah bisnis Anda.

4. Mampu menyiapkan pengambil keputusan agar dapat mengambil langkah akurat dalam menghadapi permasalahan yang ditemui.

5. Membuat pengorganisasian menjadi lebih ringan, apakah telah konsisten dengan tujuan akhir atau belum.

Business plan yang kurang sempurna dapat menyebabkan kegagalan serius di kemudian waktu karena sejumlah faktor:

a. sasaran yang dikukuhkan oleh pemimpin tidak rasional.

b. Pelaku bisnis belum memiliki pengetahuan dan pengalaman tatkala merencanakan kegiatan bisnis.

c. Pemimpin tidak mampu menangkap ancaman serta kelemahan dari bisnisnya sendiri.

d. Konsumen tidak menginginkan adanya jasa atau produk yang disediakan oleh perusahaan.

\section{G. Term of reference (TOR)}

Kerangka acuan (Term of Reference - TOR) adalah ilustrasi tujuan, struktur, dan ruang lingkup sebuah kegiatan yang disepakati untuk dikerjakan bersama agar mencapai hasil yang lebih ideal. 
TOR adalah outline dari sebuah kegiatan, yang menjelaskan struktur dan tujuan sebuah proyek, permufakatan, dan perundingan sebelum acara dimulai. Meski hanya berupa garis besar, TOR harus diusahakan untuk merangkum inti gagasan, sehingga tim bisnis / tim kerja / konsultan yang diamanati tugas memahami apa yang dipreferensikan oleh Anda sebagai pemilik bisnis / pemimpin.

Business plan berisi mekanisme sistematis perumusan dan penyusunan sebuah acara, yang biasanya diserahkan ke pihak eksternal untuk menjelaskan kegiatan serta untuk tujuan perolehan budget. Business plan lebih terperinci dari TOR. Sedangkan TOR memuat ruang lingkup juga batas kegiatan yang ditangguhkan pada kelompok kerja (internal) agar pelaksanaan kegiatan selalu konsisten dengan harapan si pengambil keputusan.

\section{H. Perencanaan Keuangan}

Salah satu peran penting business plan bagi kesuksesan proyek adalah proses perencanaan keuangan. Sering ditemui bahwa kegagalan sebuah proyek disebabkan lemahnya perencanaan dan pengelolaan keuangan acara.

Perencanaan keuangan adalah ilmu mengenai kajian keuangan dengan memperhitungkan berbagai atribut finansial 
secara sistematis dan terkonsep, baik di jangka pendek atau di jangka panjang.

Perencanaan keuangan menyiapkan petunjuk bagi pergeseran dan pertumbuhan yang timbul di perusahaan. saat suatu perusahaan berkemauan untuk mewujudkan perubahan yang berkarakter berkelanjutan, maka perancangan keuangan harus berkarakter jangka panjang. Begitupun sebaliknya.

Dalam perencanaan keuangan secara konvensional, terdapat tiga kategori berdasarkan waktu perencanaan

1. Perencanaan jangka panjang, dibuat untuk jangka waktiu lebih dari 5 tahun.

2. Perencanaan jangka menengah, dibuat untuk jangka waktu 1 - 5 tahun. Perencanaan jangka menengah umumnya dibuat sebagai support untuk planning jangka panjang.

3. Perencanaan jangka pendek, dibuat untuk jangka waktu 1 tahun / 12 bulan.

Perencanaan jangka panjang diciptakan untuk memastikan sebuah perusahaan mampu mendapat stabilitas kemajuan, kesempatan dalam berekspansi, serta mengimplementasikan inovasi dengan berkelanjutan. 
Dalam usaha membuat perencanaan keuangan yang baik, manajer keuangan harus menempatkan pemikiran dari sudut efektifitas dan efisiensi sebagai pola berpikirnya dalam merumuskan rencana keuangan.

Dalam penciptaan rencana keuangan pada business plan, pemimpin harus memperhitungkan mengenai kejadian yang berpotensi terjadi pada kemudian hari. Generally, terdapat 3 situasi yang harus diantisipasi:

a. Kondisi buruk. Dalam situasi ini, dunia bisnis dicengkeram oleh berbagai musabab: krisis moneter, resesi ekonomi, bencana alam, peperangan, inflasi tinggi, dll. Asumsi pengelolaan keuangan yang dipakai adalah agar perusahaan mampu bertahan sampai pada masa yang lebih baik.

b. Kondisi normal. Perkiraan manajemen keuangan yang dipakai adalah analisis kewaspadaan jika suatu waktu terjadi kondisi yang negatif.

c. Kondisi baik. Dalam kondisi ini, bisnis melaju sangat pesat karena dipengaruhi keadaan ekonomi yang positif atau pemasaran yang sukses. Perkiraan pengelolaan keuangan yang dipakai melibatkan pengembangan jasa atau produk baru, serta kemungkinan memulai ekspansi ke pasar yang baru. 
Dalam sebuah perencanaan bisnis, pengendalian pada keuangan berarti perusahaan menciptakan tujuan dan arti yang jelas kepada stakeholder. Pengendalian tersebut akan memberikan statemen yang jelas kepada stakeholder bahwa perusahaan dan pengambil keputusan melakukan hal yang terbaik untuk memenuhi kepentingan mereka.

Untuk tujuan perencanaan dan pengendalian keuangan, pengambil keputusan harus bisa memahami asumsi perencanaan dan pengendalian:

1. perencanaan dan pengendalian keuangan disusun dan dikonsep dengan tujuan memperkecil resiko yang terjadi di masa depan.

2. perencanaan dan pengendalian keuangan dibuat untuk memenuhi target atau prioritas tertentu.

3. perencanaan dan pengendalian keuangan harus mampu mendeteksi berbagai peristiwa dinamis sehingga langkah pencegahan dapat diterapkan.

\section{Time Schedule}

Dalam membangun business plan yang baik dan bersifat sustainable, dibutuhkan pembuatan rencana yang sistematis. Time schedule memiliki peran yang besar untuk terbentujnya pelaksanaan pekerjaan yang terencana. 
Terdapat tiga tujuan umum pembuatan time schedule yang dilakukan oleh manajer:

a. Membuat pekerjaan lebih terfokus, dan mengedepankan penyelesaian pekerjaan berdasarkan skala prioritas.

b. Diharapkan setiap pekerjaan dapat diselesaikan secara terjadwal.

c. Diharapkan setiap pekerjaan dapat diselesaikan dengan standar kualitas yang dapat dipertanggungjawabkan.

Tabel 2.1 time schedule

\begin{tabular}{|c|c|c|c|c|c|c|c|c|c|c|c|c|c|}
\hline \multirow[t]{2}{*}{ No } & \multirow[t]{2}{*}{ Kegiatan } & \multicolumn{4}{|c|}{ Bulan I } & \multicolumn{4}{|c|}{ Bulan II } & \multicolumn{4}{|c|}{ Bulan III } \\
\hline & & 1 & 2 & 3 & 4 & 1 & 2 & 3 & 4 & 1 & 2 & 3 & 4 \\
\hline 1 & Observasi & & & & & & & & & & & & \\
\hline 2 & Sosialisasi Kegiatan & & & & & & & & & & & & \\
\hline 3 & $\begin{array}{l}\text { Pelatihan dan } \\
\text { Pendampingan } \\
\text { Hidroponik }\end{array}$ & & & & & & & & & & & & \\
\hline 4 & Pelatihan Manajemen & & & & & & & & & & & & \\
\hline 5 & $\begin{array}{l}\text { Pelatihan Pencatatan } \\
\text { Akuntansi Sederhana }\end{array}$ & & & & & & & & & & & & \\
\hline 6 & $\begin{array}{l}\text { Monitoring dan } \\
\text { Evaluasi }\end{array}$ & & & & & & & & & & & & \\
\hline
\end{tabular}




\section{J. Contingency Plan}

Contingency Plan adalah rencana cadangan yang dibuat untuk mengantisipasi kemungkinan dari gagalnya rencana inti.

Contingency Plan dalam perspektif keuangan dapat diputuskan dalam bentuk memiliki cadangan aset cair (liquid reserve) yang dapat digunakan sewaktu waktu.

\section{K. Soal Soal}

1. Menurut pemahaman Anda, apakah etika diperlukan dalam sebuah pengambilan keputusan manager dalam pengelolaan unit bisnisnya? jelaskan!

2. Tipe kriteria apa yang menurut Anda paling baik digunakan dalam 4 kriteria pengambilan keputusan? jelaskan!

3. Jelaskan jenis jenis konflik yang ada dalam organisasi dan bagaimana cara meresolusi konflik tersebut!

4. Terangkan mengenai business plan dan kegunaannya!

5. Kondisi apa yang perlu Anda perhatikan dalam pembuatan rencana keuangan dalam business plan agar rencana keuangan menjadi lebih akurat? Jelaskan! 


\section{Pohon Keputusan}

\section{A. Pohon Keputusan (PK)}

Dalam mendukung pengambilan keputusan untuk menghasilkan tujuan yang diharapkan, pohon keputusan (decision tree) dapat dipakai sebagai salah satu sarana pendukung perwujudan tersebut.

Pengambilan keputusan dengan mempergunakan pohon keputusan umumnya digunakan oleh manajer untuk melihat persoalan masalah secara jauh lebih berkerangka (framework) dan memetakan seluruh alternatif-alternatif pemecahan masalah yang dapat diambil dari masalah tersebut.

Dalam bab ini, kita akan membahas tentang pengambilan keputusan dengan menggunakan pohon keputusan sebagai sarana pendukungnya. Untuk memudahkan proses dalam pengambilan keputusan agar lebih komprehensif, penggunaan pohon keputusan dapat membantu Anda dalam mengambil keputusan secara lebih terang dan sederhana.

Menurut Welch \& Corner, pohon keputusan merupakan suatu diagram yang cukup sederhana yang menunjukan suatu proses untuk merinci masalah yang dihadapinya ke dalam komponen, kemudian 
dibuatkan alternatif pemecahan beserta konsekuensi untuk masing masing alternatif.

Menurut Supranto, pohon keputusan merupakan suatu diagram berupa pohon bercabang yang menghubungkan antara alternatif keputusan / tindakan dengan kejadian yang tidak pasti yang melingkupi setiap alternatif keputusan yang dipilih.

\section{B. Prosedur Dan Tahap Pembuatan PK}

Untuk membuat pohon keputusan, terdapat beberapa prosedur yang harus diikuti. Menurut Heizer \& Render, untuk membangun pohon keputusan, kita akan menggunakan prosedur berikut:

1. Pastikan bahwa seluruh alternatif dan keadaan alami yang mungkin terjadi dimuat kedalam pohon. Jika dibutuhkan, pilihan solusi dapat mencakup alternatif dari tindakan "tidak melakukan apapun"

2. konsekwensi (positif / negatif) diinput pada akhir cabang yang sesuai. konsekwensi tersebut merupakan efek dari sebuah peristiwa yang akan kita alami jika mengambil sebuah ranting keputusan / jalur keputusan tertentu.

3. Tujuan dari pohon keputusan adalah untuk menentukan nilai ekspektasi dari masing-masing tindakan. Untuk menentukan nilai, dapat diuji dengan metode pengambilan keputusan. 


\section{PK dan Pengambilan Keputusan}

Dalam membuat pohon keputusan, terdapat symbol yang secara umum digunakan:

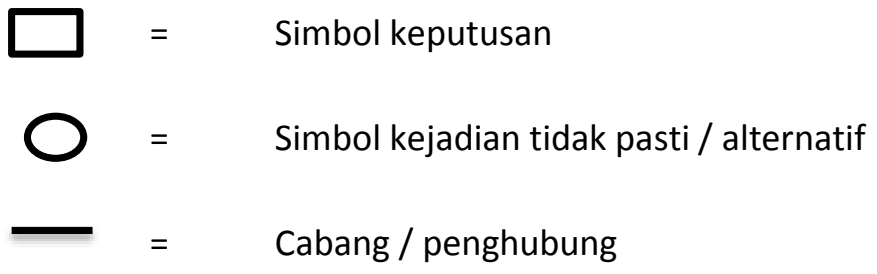

Gambar 3.1 pohon keputusan

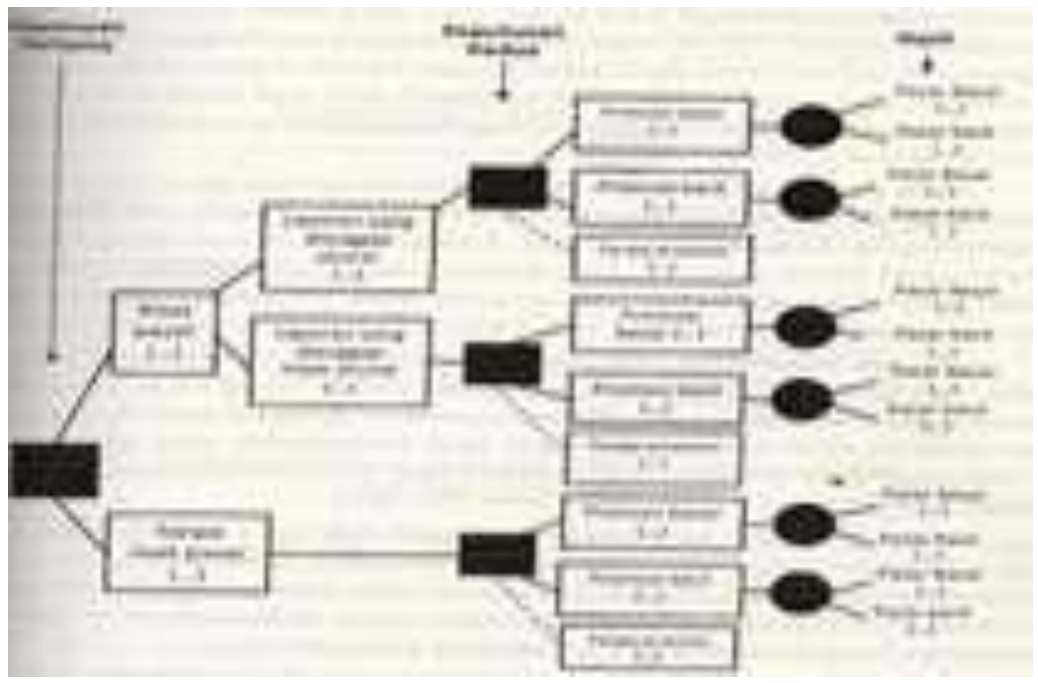

Dari gambar, dapat dipahami bahwa keputusan pertama (first decision point) merupakan tahap awal sebuah keputusan yang diambil terhadap sesuatu yang hendak dikaji atau dianalisis. 
Pada keputusan kedua, (second decision point) telah terbentuk dua sisi keputusan. Sisi pertama adalah berdasarkan riset pasar atau melakukan kajian langsung, sisi kedua menggunakan data primer yang di dapat dari tahun tahun sebelumnya tanpa melakukan riset pasar.

Pada keputusan ketiga, perusahaan memutuskan untuk melakukan promosi besar, promosi kecil, dan tanpa promosi. Kemudian keputusan tersebut diaplikasikan pada pasar besar dan pasar kecil. Melalui perhitungan cost dalam promosi besar maupun kecil dan implikasi pemasaran yang timbul dalam pasar besar dan kecil, pengambil keputusan dapat memilih konsekwensi yang paling positif dari pohon keputusan.

Pembuatan pohon keputusan bertujuan untuk membantu para manajer dalam merinci dan melihat peta keputusan dari perspektif pohon keputusan.

\section{Contoh 2}

Mr. Mastera adalah seorang investor pemula dimana ia memiliki uang sebesar Rp 1 miliar dan berkeinginan melakukan investasi dalam penanaman coklat.

Selama ini ia hanya mendepositokan uangnya di bank dan memperoleh keuntungan dengan dalam bentuk bunga deposito. 
Maka untuk pembuatan pohon keputusan sederhana, bisa kita buat sebagai berikut:

gambar 2.2 Keputusan Inventor dalam Menanam Coklat atau mendepositkan Uang

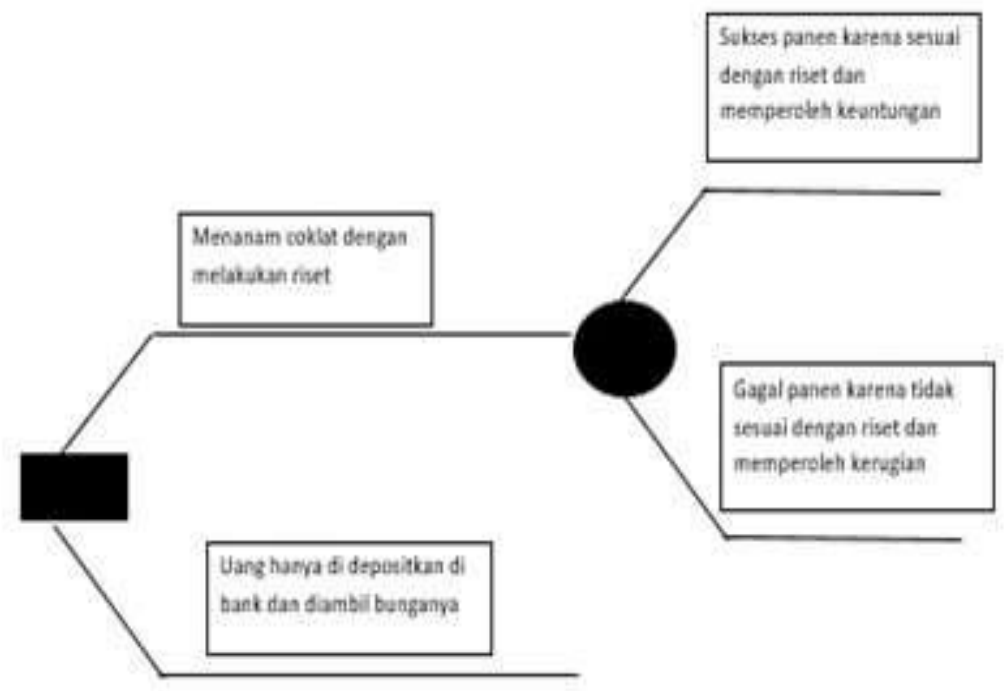

Pada gambar sebelumnya, Mr. Mastera memiliki dua kondisi alternatif keputusan: ia mendepositokan uang di bank dengan mendapatkan keuntungan yang stabil dan terbatas, atau melakukan keputusan investasi dalam penanaman coklat dan mendapatkan berbagai kemungkinan yang dapat terjadi.

Kondisi sukses panen membuat ia mendapat keuntungan yang berlipat, namun jika gagal panen ia akan menelan kerugian. Posisi untung rugi tersebut sangat dipengaruhi oleh kualitas riset pasar 
yang dilakukan, karena hasil riset sering dijadikan rujukan dalam memprediksi kondisi ke depan.

\section{Contoh Soal PK}

Contoh 3 : Pohon keputusan untuk kasus perekrutan atau tidak untuk karyawan perusahaan.

Manajer keuangan PT Menara Indah sedang mempertimbangkan ususlan dari manajer SDM tentang penambahan tenaga kerja. Penambahan tenaga kerja dilakukan dengan teknik perekrutan.

Salah satu tujuan penambahan tenaga kerja adalah meningkatkan kapasitas produksi yang berpengaruh pada peningkatan penjualan dan laba perusahaan.

Namun, di sisi lain ada permasalahan lain yang timbul yaitu perusahaan harus menyediakan alokasi dana khusus untuk perekrutan.

Perusahaan dapat memakai tenaga konsultan yang berasal dari lembaga lain sebagai tim seleksi, tetapi biaya akan semakin tinggi.

Perusahaan dapat memanfaatkan tim SDM perusahaan sendiri, sehingga biaya rekrutmen dapat ditekan. 
gambar 3.3 Keputusan sdm perusahaan

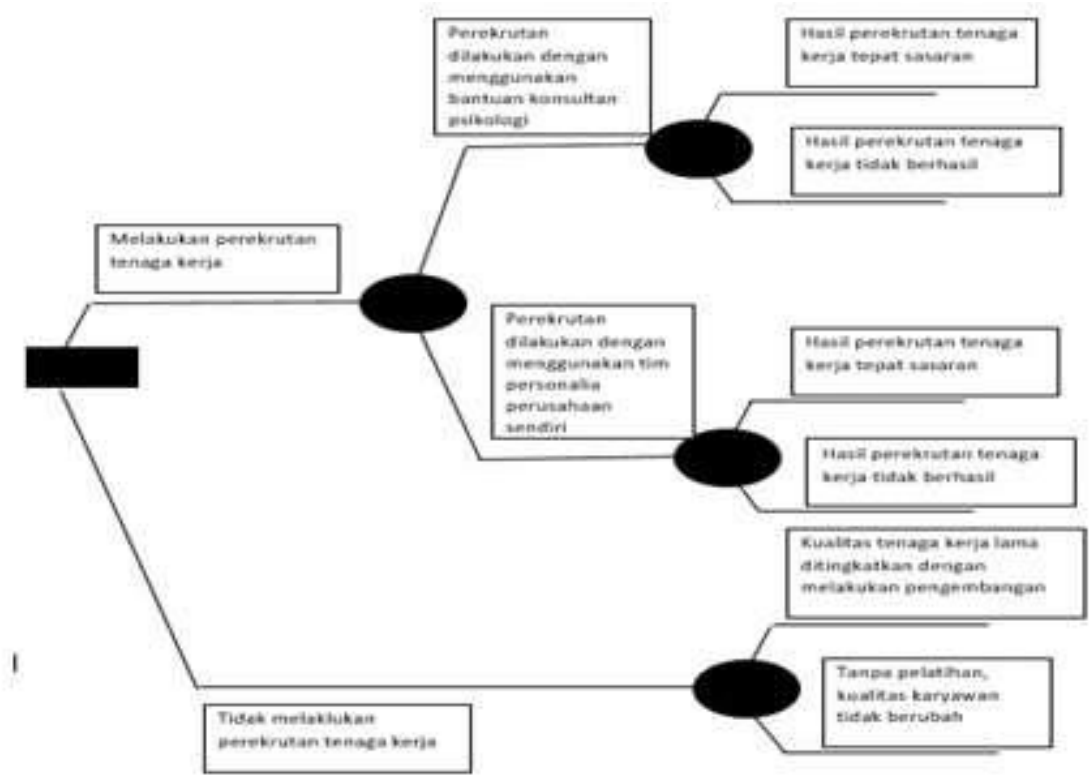

Contoh 4 : Pohon keputusan untuk analisis meningkatkan, mempertahankan, dan mengembangkan produktifitas perolehan keuntungan pabrik silica gel pada 3 kondisi ekonomi. 
Tabel 3.1 produktifitas perolehan keuntungan pabrik silica gel

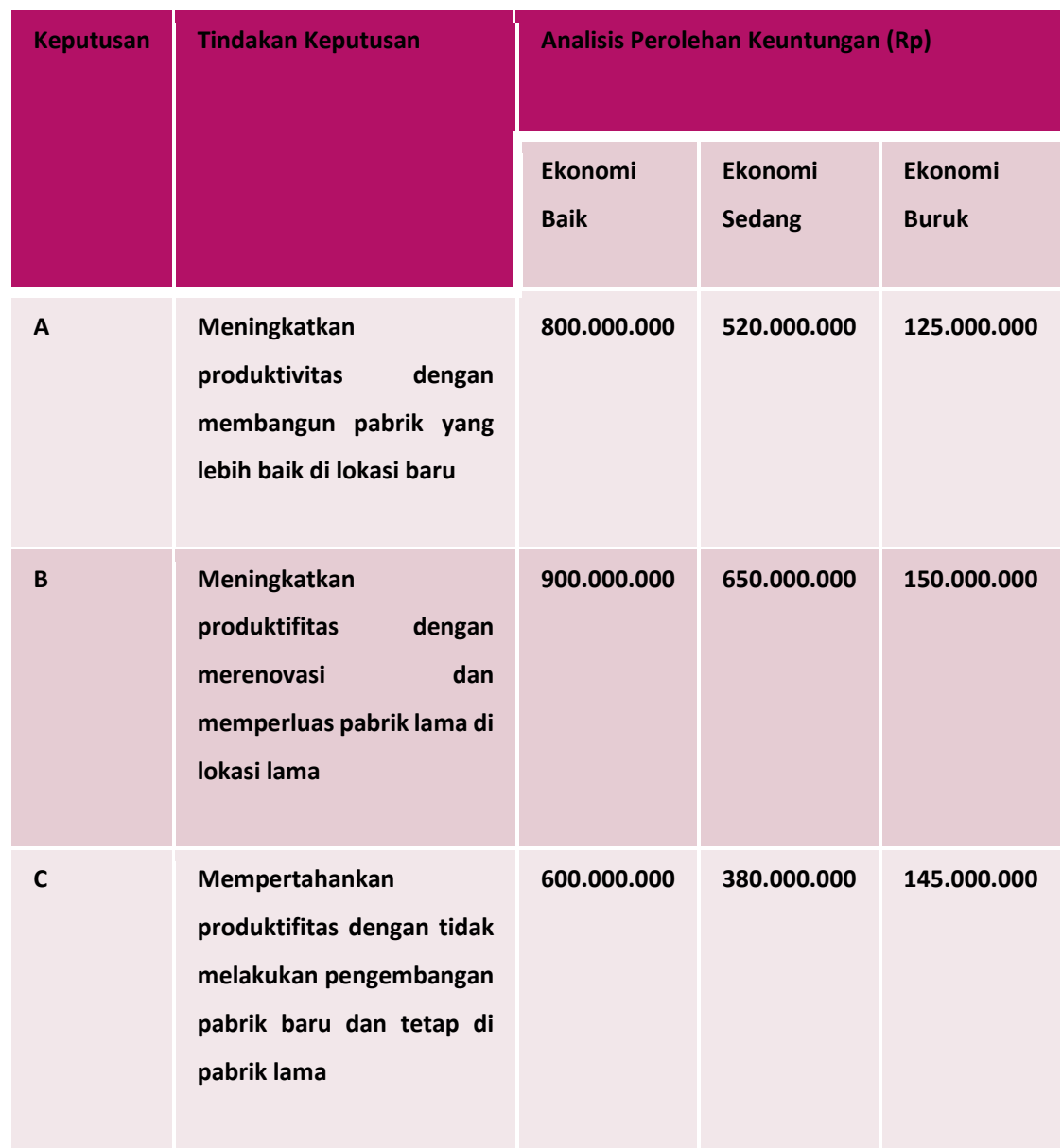


Gambar 3.4 produktifitas perolehan keuntungan pabrik silica gel

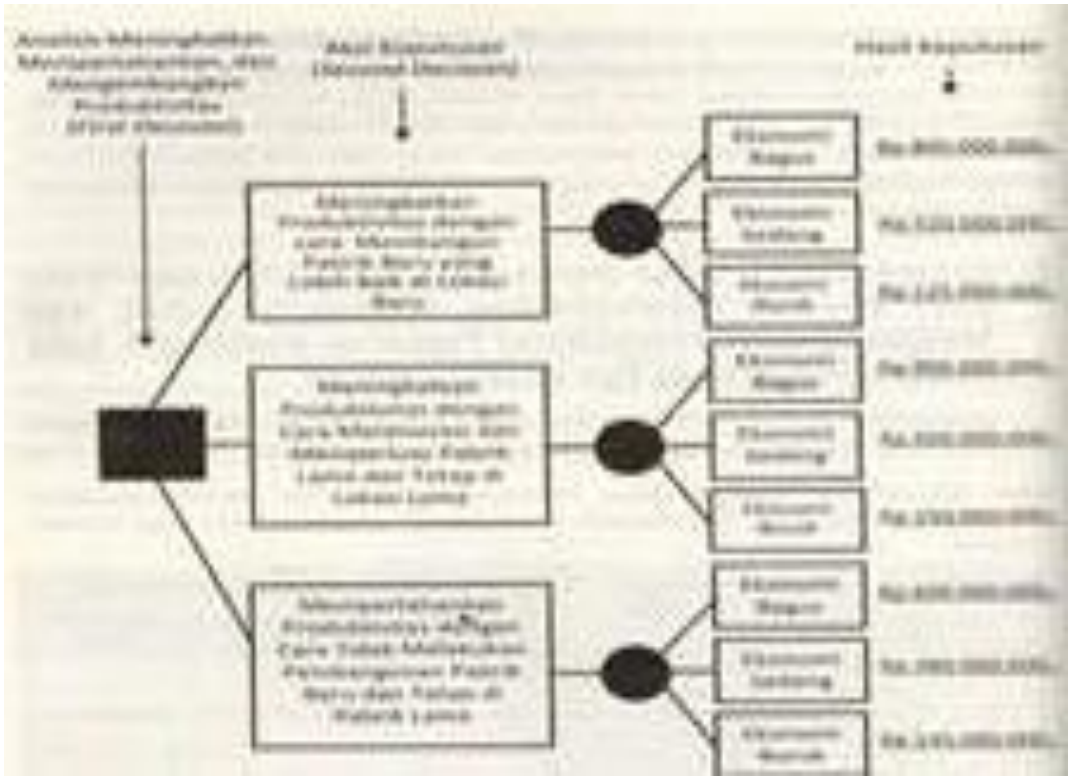

Contoh 5 : Pohon keputusan untuk pendekatan kasus konflik manajemen perusahaan dan karyawan

Manajer SDM PT Bumi Alam Muda sedang mengalami permasalahan dalam ketenagakerjaan. PT Bumi Alam Muda adalah perusahaan Real Estate yang sedang melakukan pengembangan perumahan dan termasuk perusahaan yang memiliki reputasi yang baik di mata publik maupun mita bisnisnya.

Masalah timbul saat salah seorang supervisor yang bertugas mengontrol pekerjaan melakukan protes karena karyawan di divisinya tidak mendapatkan jaminan kesehatan yang layak. Dalam 
pengerjaan proyek yang sedang berlangsung, terdapat 6 orang karyawan yang mengalami kecelakaan kerja, namun perusahaan hanya menanggung $40 \%$ biaya pengobatan.

Kondisi ini menurut karyawan adalah tidak layak dan membuat karyawan melakukan protes dan menginginkan perusahaan memberi jaminan kesehatan $100 \%$.

Namun di sisi lain, pihak manajemen perusahaan telah menjelaskan semenjak awal penandatanganan kontrak kerja bahwa perusahaan hanya bersedia menanggung $40 \%$ dari setiap kejadian kecelakaan, tidak ada satu pun isi perjanjian kontrak yang mengatakan bahwa perusahaan akan menanggung biaya $100 \%$.

Permasalahan bertambah rumit saat pihak karyawan berencanan menggugat manajemen perusahaan ke pengadilan, bahkan menyewa pengacara handal.

Dari diskusi intenal perusahaan yang intensif, terdapat tiga bentuk hasil akhir yang bisa didapat untuk menyelesaikan permasalahan ini. Tiga hasil akhir tersebut dapat ditaksir dalam bentuk pengeluaran biaya sebagai berikut:

Kondisi pertama, jika kasus dimenangkan oleh pihak manajemen, maka taksiran biaya yang ditanggung oleh perusahaan adalah: 
- Pihak perusahaan dapat melanjutkan proyek pengembangan sesuai dengan isi kontrak, namun manajemen harus menanggung kerugian terhentinya proyek selama masa persidangan sebesar Rp. 1.500.000.000.

- Jika perusahaan berencana menyewa pengacara, maka biaya pengacara ditaksir sebesar Rp. 40.000 .000

- Biaya selama berlangsungnya proses peradilan, yaitu biaya transportasi dan akomodasi ditaksir sebesar Rp. 4.000.000

- Biaya lain lain sebesar Rp. 40.000.000, mencakup biaya tak terduga yang terjadi selama berlangsungnya proses sengketa.

Kondisi kedua, jika kasus dimenangkan oleh pihak karyawan, maka taksiran biaya yang ditanggung oleh perusahaan adalah:

- Jika gugatan dimenangkan oleh pihak karyawan, perusahaan harus mengganti biaya kecelakaan kerja dan kesehatan sebesar Rp. 180.000.000.

- Biaya selama berlangsungnya proses peradilan, yaitu biaya transportasi dan akomodasi ditaksir sebesar Rp. 4.000.000

- Jika perusahaan berencana menyewa pengacara, maka biaya pengacara ditaksir sebesar Rp. 40.000 .000

- Pihak perusahaan dapat melanjutkan proyek pengembangan sesuai dengan isi kontrak, namun manajemen harus menanggung kerugian terhentinya proyek selama masa persidangan sebesar Rp. 1.500.000.000. 
- Biaya lain lain sebesar Rp. 40.000 .000 , mencakup biaya tak terduga yang terjadi selama berlangsungnya proses sengketa.

Kondisi ketiga, jika pihak manajemen memilih menyelesaikan masalah dengan cara damai atau win win solution, maka taksiran biaya yang dikeluarkan perusahaan adalah:

- Pihak perusahaan mengganti kerugian dan menjamin $100 \%$ biaya jaminan kesehatan seluruh karyawan. Perusahaan juga mengganti biaya pengobatan 6 karyawan yang mengalami kecelakaan kerja sebesar @ 21.000.000 x 6 orang = Rp. 126.000 .000

- Biaya asuransi jaminan kesehatan untuk seluruh karyawan ditaksir satu bulannya perusahaan harus menyetor ke perusahaan asuransi sebesar Rp. 12.500 .000

- Biaya asuransi jaminan kematian bagi keluarga yang ditinggal, perusahaan ditaksir harus menyetor ke perusahaan asuransi sebesar Rp. 11.500 .000

- Biaya tambahan kontrol terhadap supervisor sebesar @ $700.000 \times 4$ supervisor $=$ Rp. 2.800 .000 . biaya ini dimaksudkan untuk pengontrolan ketat agar mampu menekan angka kecelakaan kerja.

- Biaya lain lain Rp. 8.000.000 per bulan. Mencakup biaya yang dikeluarkan untuk membangun keakraban dan kekeluargaan antara manajemen dan karyawan. 
Berdasarkan penjelasan diatas, kita dapat membuat pengambilan keputusan sebagai berikut:

Gambar 3.5 pendekatan kasus konflik manajemen perusahaan dan karyawan

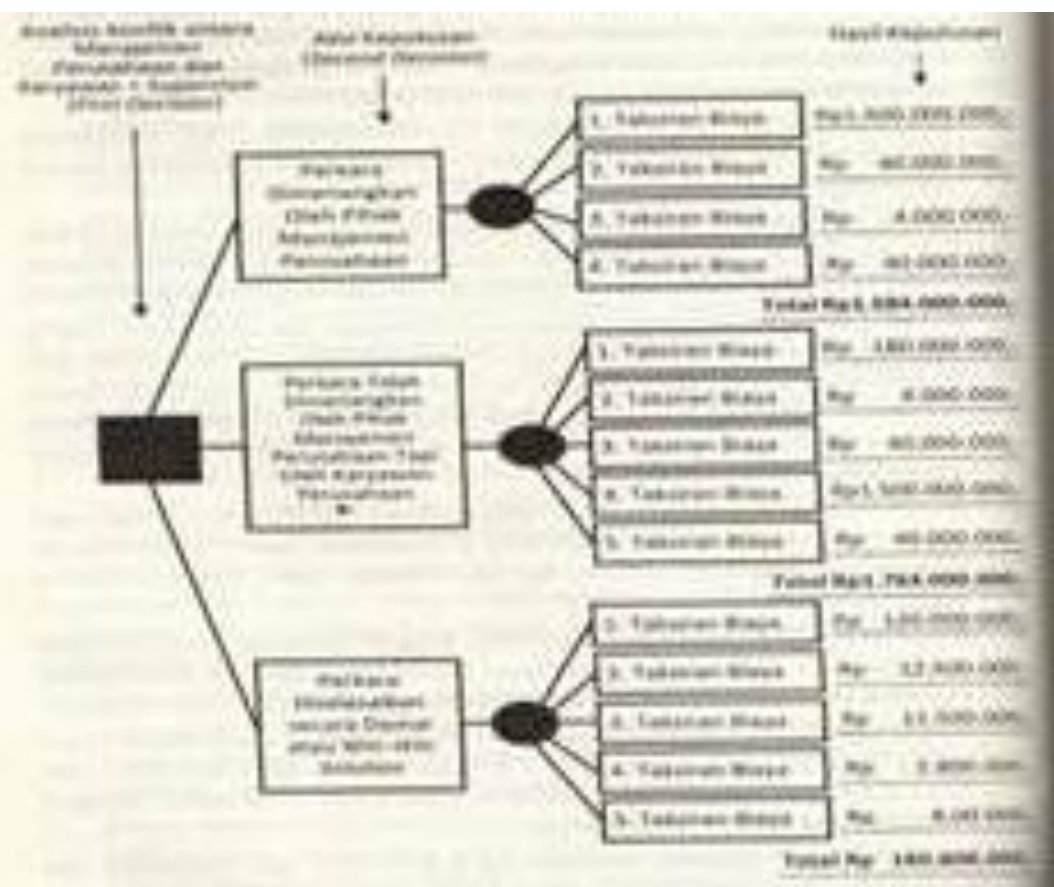

Dari hasil perhitungan tsb, akan terlihat keseluruhan permasalahan yang telah disusun secara sistematis. Hasil efisien yang dapat dipilih berdasarkan pohon keputusan adalah win win solution. 


\section{E. Perilaku Pengabaian Terhadap Sinyal Kegagalan}

Model pengambilan keputusan, baik dengan teknik apapun yang kalian gunakan, menunjukan sejumlah langkah tertentu dalam penyelesaian masalah.

Seluruh aktifitas ditunjang dengan keberadaan informasi. Semenjak informasi hanya merupakan input, nilai sebenarnya dari informasi terletak pada pandangan pengambil keputusan. Artinya, setinggi apapun nilai informasi, tetap tidak akan digunakan jika manajer menolak atau tidak menggunakan informasi tersebut.

Pandangan yang berbeda terhadap informasi pada setiap individu pengambil keputusan merupakan sebuah kewajaran, karena setiap manajer mungkin memiliki permasalahan yang berbeda. Jika keputusan dibuat secara objektif, perbedaan pandangan tidak akan menjadi masalah karena keputusan diambil untuk memecahkan masalah yang sebenarnya. Sebaliknya, penilaian informasi secara subyektif / untuk tujuan tertentu yang tak berkaitan dengan pemecahan masalah dapat mendorong manajer pada keputusan yang tidak tepat.

Telah kita pelajari sebelumnya, ketidakakuratan informasi yang disebabkan oleh ketidakpastian yang tinggi sering kali menjadi penyebab utama seorang manajer mengambil keputusan yang tidak tepat. 
Namun hal yang berbeda akan terjadi saat pengambil keputusan menentukan keputusan secara subyektif sehingga mengabaikan sejumlah sinyal, tanda, atau isyarat (informasi lain yang lebih akurat, nasihat, atau peringatan) yang menunjukan bahwa keputusan yang diambil tidak tepat.

Saran atau nasihat dari pihak lain (pihak di luar penentu keputusan akhir) tentunya telah mengalami pengolahan informasi secara sistematis sehingga informasi bernilai akurat dan berkualitas. Tetapi karena manajer memiliki motif tertentu (subyektif) dalam pengambilan keputusan, saran atau nasihat tersebut tidak akan diperhatikan.

Pembukaan lahan sejuta gambut di Kalimantan Tengah dan reklamasi pantai indah Kapuk di Jakarta Utara merupakan satu dari banyak contoh nyata kerugian mengenai pengabaian informasi yang bersumber dari pihak di luar penentu keputusan akhir oleh penentu keputusan.

Amdal (analisa mengenai dampak lingkungan) memberikan sinyal bahwa pembukaan lahan gambut dan reklamasi pantai sesungguhnya memberikan kerugian yang lebih 
besar daripada manfaat. Namun penentu keputusan akhir tidak mau berkompromi dengan merubah keputusan walau terdapat bukti nyata mengenai bobroknya keputusan yang diambilnya.

Pelajaran apa yang bisa kita ambil dari kasus tersebut?

1. Akan selalu ada informasi lain yang bernilai "obyektif" di luar informasi hasil olahan sendiri untuk dijadikan pertimbangan dalam keputusan final.

2. Munculnya informasi lain selain informasi utama mengarahkan tindakan pada dua bentuk konsekuensi: berhasil atau gagal dalam sebuah keputusan.

3. Kecendrungan perilaku pengabaian atas sinyal kegagalan sering kali membawa manajer dalam pengambilan keputusan yang salah dan kegagalan.

4. Perilaku pengabaian atas sinyal kegagalan menghasilkan peningkatan tindakan yang menuju kegagalan yang fatal secara perlahan. 


\section{F. Faktor Penyebab Perilaku Pengabaian}

Faktor psikologis dan faktor sosial menunjukan kehadiran ego dan keinginan menjaga reputasi diri. Tentunya orang enggan untuk mengakui kesalahan dan kegagalan, terlebih bila suatu tindakan dihubungkan dengan nilai kegiatan bisnis yang memiliki prestise tinggi.

Faktor proyek lebih berfokus pada tingkat pengembalian kegiatan bisnis yang tidak segera dapat diraih. Karakteristik ini menyebabkan manajer cenderung menunggu untuk melakukan tindakan. Semakin lama manajer melakukan "wait and see", semakin kecil peluang untuk melakukan hal lain yang mungkin lebih berharga.

Faktor organisasi menunjukan adanya "permainan politik dalam organisasi" pada pengambilan keputusan. Minat terselubung dapat ditunjukan oleh beberapa orang yang berpengaruh di organisasi dan menjadi faktor utama mengapa sebuah keputusan yang salah tetap diaplikasikan 


\section{Faktor Psikologis}

1. Kecendrungan

melakukan

penyimpangan

2. Pandangan egosentris

3. Perilaku pencarian kambing hitam

4. Keengganan mengakui kesalahan

5. Motivasi meraih prestise dan reputasi
6. Dorongan

menjaga

reputasi diri

7. Pandangan "bos tidak pernah salah"

8. Tingkat keberanian mengambil resiko

9. Over confident

10 Keterbatasan

kemampuan

\section{Faktor Sosial}




\begin{tabular}{|l|l|l|l|}
\hline $\begin{array}{l}\text { 1. } \\
\text { mempertahankan } \\
\text { status sosial }\end{array}$ & 5. & $\begin{array}{l}\text { Adanya tekanan dari } \\
\text { "pemimpin tertinggi }\end{array}$ \\
\hline 2. & $\begin{array}{l}\text { Penerimaan praktik } \\
\text { KKN }\end{array}$ & & \\
\hline 3. & Kehadiran nasehat yang & 6. & Pandangan atas budaya \\
\hline menyesatkan & "serba boleh" \\
\hline & Pengaruh hirarki sosial & 7. & Perbedaan cara pandang \\
\hline & & & budaya \\
\hline
\end{tabular}

\section{Faktor Organisasi}

Lingkungan Eksternal

Lingkungan Internal

1.

Perubahan

budaya organisasi yang

kondisi ekonomi

buruk

2. Kehadiran keinginan

2.

terselubung 


\begin{tabular}{|c|c|c|c|}
\hline 3. & $\begin{array}{l}\text { Perselisihan antar } \\
\text { kelompok }\end{array}$ & & $\begin{array}{l}\text { Perubahan } \\
\text { pandangan sosial } \\
\text { budaya }\end{array}$ \\
\hline 4. & $\begin{array}{l}\text { Rendahnya } \\
\text { pandangan \& } \\
\text { pertimbangan etika }\end{array}$ & 3. & $\begin{array}{l}\text { Pengaruh situasi } \\
\text { politik }\end{array}$ \\
\hline 5. & $\begin{array}{l}\text { Sistem pengawasan } \\
\text { kinerja dan perilaku } \\
\text { yang buruk }\end{array}$ & 4. & $\begin{array}{l}\text { Hubungan bisnis } \\
\text { yang tidak sehat }\end{array}$ \\
\hline 6. & $\begin{array}{l}\text { Rentang hirarki dan } \\
\text { birokrasi yang tinggi }\end{array}$ & 5. & $\begin{array}{l}\text { Tingkat } \\
\text { kompetisi bisnis yang } \\
\text { semakin tinggi }\end{array}$ \\
\hline 7. & $\begin{array}{l}\text { Model } \\
\text { kepemimpinan otoriter }\end{array}$ & & \\
\hline 8. & $\begin{array}{l}\text { Sistem komunikasi } \\
\text { yang buruk }\end{array}$ & & \\
\hline 9. & $\begin{array}{c}\text { Politik dalam } \\
\text { organisasi }\end{array}$ & & \\
\hline
\end{tabular}




\section{Faktor dari nilai keputusan}

1. Tujuan yang hendak dicapai menghasilkan keuntungan besar

2 Penyelesaian masalah atau pencapaian tujuan memberikan prestise yang tinggi
$7 . \quad$ Pandangan "tidak ada jalan mundur"

8.

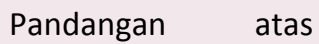
“informasi yang bernilai subyektif"

\begin{tabular}{|c|c|c|c|}
\hline 3 & $\begin{array}{l}\text { Tindakan akan } \\
\text { menhasilkan } \\
\text { kemenangan atas lawan } \\
\text { kompetisi bisnis }\end{array}$ & 9. & $\begin{array}{l}\text { Harapan atas } \\
\text { "kemunculan peluang } \\
\text { keberhasilan" }\end{array}$ \\
\hline 4 & \begin{tabular}{l}
\multicolumn{2}{c}{ Besarnya biaya yang } \\
dikeluarkan untuk \\
menghasilkan \\
keputusan dan \\
penerapannya
\end{tabular} & 10 & $\begin{array}{l}\text { Keengganan } \\
\text { menerima sinyal dari } \\
\text { pihak lain }\end{array}$ \\
\hline
\end{tabular}




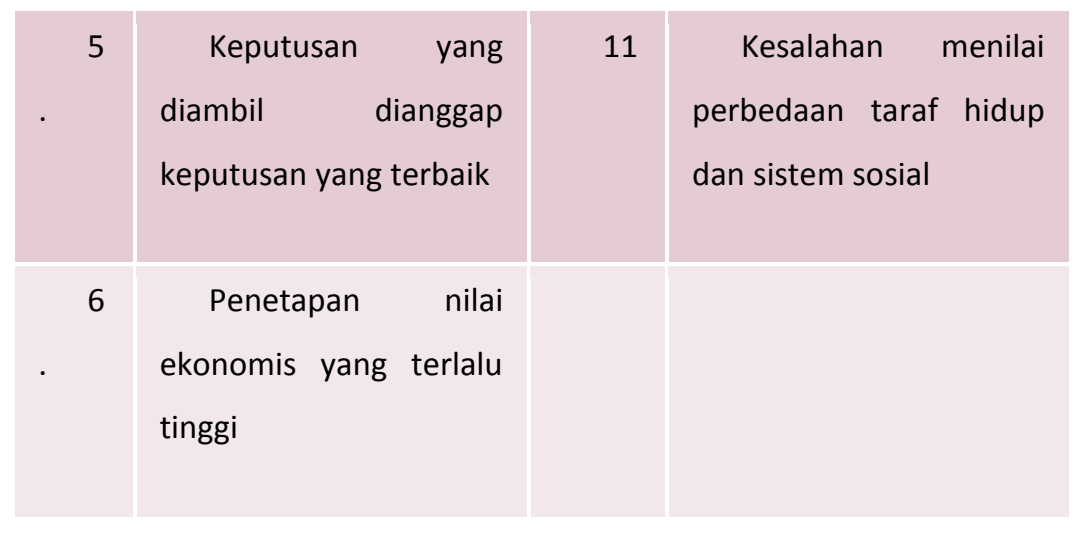

\section{G. Soal Soal}

1. Buatlah decision tree mengenai permasalah berikut!

Anda adalah seorang pebisnis yang sedang mengembangkan usaha Anda. Melalui pembuatan business plan yang baik, Anda dapat mengetahui kelemahan yang ada pada bisnis Anda, yaitu (1) permasalahan rantai pasokan, (2) skill yang dimiliki SDM, dan (3) lokasi usaha yang kurang strategis. Anda memiliki modal sebesar 40 juta Rupiah, tetapi modal tersebut hanya dapat membenahi 1 dari 3 kelemahan yang bisnis Anda.

Jika Anda memprioritaskan rantai pasokan, Anda memilih untuk mengabaikan peningkatan skill SDM dan pencarian lokasi usaha baru. Taksiran biaya yang diperlukan adalah: pembenahan internal supply chain perusahaan sebesar 10 juta, merancang 
desain upstream supply chain sebesar 15 juta, menciptakan proses downstram supply chain sebesar 15 juta.

Jika Anda memprioritaskan peningkatan skill SDM, maka Anda memilih untuk mengabaikan perbaikan rantai pasokan dan pencarian lokasi usaha baru. Taksiran biaya yang diperlukan adalah: pelatihan soft skill sebesar 12 juta, pelatihan kreatifitas sebesar 8 juta, pelatihan kerja sama tim sebsar 7 juta, pelatihan kepemimpinan sebesar 9 juta, dan pelatihan etika sebesar 4 juta.

Jika Anda memprioritaskan pencarian lokasi usaha baru maka Anda memilih untuk mengabaikan perbaikan rantai pasokan dan peningkatan skill SDM. Taksiran biaya yang diperlukan adalah: survey kelayakan bisnis sebesar 9 juta, biaya sewa tempat usaha baru sebesar 25 juta, dan pembuatan saluran sirkulasi udara di tempat usaha baru sebesar 6 juta. 


\section{Teknik Pengambilan Keputusan \\ secara Sederhana}

\section{A. Analisis Perbandingan Sepasang}

Teknik analisis paired comparison merupakan metode yang baik untuk mengukur kepentingan relatif (relative importance ) dari sejumlah alternatif solusi dan tindakan. Analisis ini memudahkan kita dalam menentukan keputusan kala skala prioritas dari masalah dan solusi tidak jelas, atau ketika seluruh solusi terhadap masalah memiliki kemungkinan menarik untuk dipilih.

Langkah dalam teknik ini dapat dijabarkan sebagai berikut:

1) Membuat pertanyaan sebanyak pasangan butir yang kemungkinan dapat disusun.

2) Pertanyaan diberikan kepada responden (sekelompok orang) untuk diisi (misalnya 12 orang).

3) Hasilnya dirangkum dalam matriks prosentase

Contoh:

Membuat pertanyaan sebanyak pasangan butir yang kemungkinan dapat disusun: Misalkan jika terdapat butir 1, 2, dan 3, 
maka berdasarkan rumus di atas dapat disusun pertanyaan sebanyak tiga buah sebagai berikut:

- Manakah yang lebih baik antara butir 1 dan butir 2?

- Manakah yang lebih baik antara butir 1 dan butir 3?

- Manakah yang lebih baik antara butir 2 dan butir 3?

Pertanyaan lalu diberikan kepada responden (sekelompok orang) untuk diisi (misalnya N : 30 orang).

Hasil jawababn responden dirangkum dalam matriks prosentase,

Tabel 4.1 matriks prosentase

\begin{tabular}{|c|l|l|l|}
\hline Butir & 1 & 2 & 3 \\
\hline 1 & 0.00 & 0.75 & 0.60 \\
\hline 2 & 0.25 & 0.00 & 0.45 \\
\hline 3 & 0.40 & 0.55 & 0.00 \\
\hline
\end{tabular}

\section{B. Analisis Jaringan}

Analisis Jaringan merupakan salah satu teknik perencanaan yang digunakan dalam pendekatan riset operasional. Teknik analisis ini membantu kita dalam menentukan keputusan atas beberapa pilihan yang dihadapkan pada sejumlah faktor yang berbeda. 
Langkah dalam teknik pengambilan keputusan ini adalah:

1) Daftar seluruh pilihan yang kita tetapkan, dan seluruh faktor yang kita anggap penting dalam proses pengambilan keputusan.

2) Tempatkan keduanya dalam sebuah tabel, dimana pilihan diletakkan pada baris dan faktor kolom.

3) Tetapkan tingkat kepentingan relatif dari seluruh faktor. Tunjukan hal tersebut dalam bentuk angka. Angka digunakan untuk mengukur tingkat preferensi dengan tingkat kepentingan dari faktor tersebut.

4) Beri penilaian setiap faktor yang dipilih, dari 0 (sangat buruk) sampai 3 (sangat baik).

5) Kalikan setiap nilai yang kita berikan dengan nilai kepentingan relatif yang kita tetapkan.

6) Nilai pilihan tertinggi merupakan pilihan solusi yang tepat atas masalah yang kita hadapi.

Contoh:

Seseorang ingin membeli mobil yang dapat memuat banyak barang, namun juga harus dapat dipakai untuk bergaya ala tampilan pelaku bisnis yang elit dan elegan. Mobil yang diinginkan juga harus memiliki tampilan layaknya sport car. Mobill apa yang dia pilih untuk dapat memenuhi kriteria tersebut? 
Setelah mengadakan survei, orang tersebut mendapatkan pilihan berikut: (1) mobil sport, (2) mobil sedan, (3) mobil keluarga, (4) mobil four wheel drive ala mobil jip

Kriteria yang dipertimbangkan: (1) harga, (2) kemampuan daya angkut barang pada kondisi normal, (3) kemampuan menyimpan barang dengan aman, (4) kenyamanan kendaraan untuk perjalanan jarak jauh, (5) keren dan terlihat menyimbolkan kebebasan dan jiwa muda, (6) terlihat bergaya dan berkualitas.

Langkah pertama yang ditempuh adalah menyiapkan tabel dengan nilai faktor yang dianggap akan memuaskan keputusan sbb:

Tabel 4.2 nilai faktor

\begin{tabular}{|c|c|c|c|c|c|c|c|}
\hline faktor & harga & $\begin{array}{l}\text { daya } \\
\text { angkut }\end{array}$ & $\begin{array}{l}\text { daya } \\
\text { simpan }\end{array}$ & kenyamanan & gaya & keren & total \\
\hline nilai & & & & & & & \\
\hline $\begin{array}{l}\text { mobil } \\
\text { sport }\end{array}$ & 1 & 0 & 0 & 1 & 3 & 3 & \\
\hline $\begin{array}{l}4 \text { wheel } \\
\text { drive }\end{array}$ & 0 & 3 & 2 & 2 & 1 & 1 & \\
\hline sedan & 2 & 2 & 1 & 3 & 0 & 0 & \\
\hline $\begin{array}{l}\text { mobil } \\
\text { keluarga }\end{array}$ & 2 & 3 & 3 & 3 & 0 & 1 & \\
\hline
\end{tabular}


Nilai tersebut dikali dengan nilai preferensi yang telah dimasukkan sebelumnya

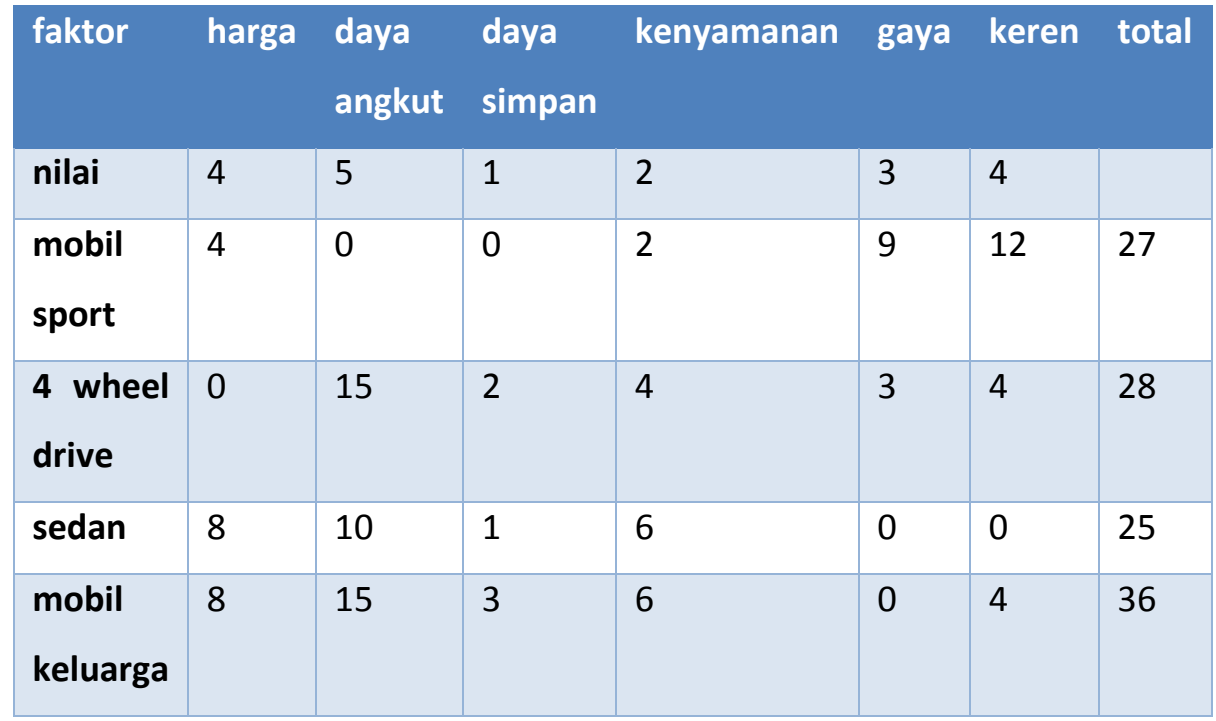

\section{Teknik Implikasi Plus Minus}

Teknik pengambilan keputusan PMI menimbang implikasi plus dan minus dari sebuah pilihan. Teknik ini digunakan untuk melihat pro kontra dari keputusan yang akan diambil.

1) Langkah dalam teknik PMI dijabarkan sebagai berikut:

2) Gambar tabel dengan judul setiap kolom: plus, minus, implikasi

3) Di kolom plus, tulis seluruh konsekuensi positif dari suatu pilihan. 
4) Di kolom minus, tulis seluruh konsekuensi negatif dari suatu pilihan.

5) Di kolom implikasi, tuliskan seluruh implikasi beserta hasil yang memungkinkan dari pilihan yang diambil, baik positif maupun negatif.

6) Tentukan nilai untuk setiap konsekwensi yang ditetapkan. Dalam hal ini, penilaian dilakukan secara subyektif. (Tetapkan skalanya!)

7) Totalkan seluruh nilai. Hasil positif menunjukkan bahwa pilihan sebaiknya diambil, nilai negatif sebaliknya.

Contoh kasus:

Sebuah perusahaan memutuskan membuka kantor cabang baru. Pilihan sementara yang diajukan adalah menentukan letak kantor di pusat kota. Bagaimana perusahaan memutuskan?

\begin{tabular}{|c|c|c|}
\hline plus & minus & implikasi \\
\hline $\begin{array}{l}\text { lebih mudah } \\
\text { dijangkau } \\
\text { pelanggan }(+5)\end{array}$ & $\begin{array}{l}\text { Biaya sewa mahal (- } \\
\text { 6) }\end{array}$ & $\begin{array}{l}\text { pengaruh } \\
\text { lingkungan yang } \\
\text { tidak kondusif }\end{array}$ \\
\hline
\end{tabular}




\begin{tabular}{|c|c|c|}
\hline & & $\begin{array}{l}\text { terhadap karyawan } \\
(-4)\end{array}$ \\
\hline $\begin{array}{l}\text { kemudahan akses } \\
\text { ke departemen } \\
\text { pemerintah (+5) }\end{array}$ & $\begin{array}{l}\text { ruang kantor yang } \\
\text { sempit (-3) }\end{array}$ & $\begin{array}{l}\text { dapat } \\
\text { mempengaruhi } \\
\text { perubahan } \\
\text { eksternal dengan } \\
\text { segera }(+1)\end{array}$ \\
\hline \multirow[t]{3}{*}{$\begin{array}{l}\text { kemudahan } \\
\text { komunikasi dengan } \\
\text { rekan bisnis (+4) }\end{array}$} & $\begin{array}{l}\text { tingkat kemacetan } \\
\text { yang tinggi }(-4)\end{array}$ & $\begin{array}{l}\text { lebih mudah } \\
\text { membangun relasi } \\
\text { bisnis }(+2)\end{array}$ \\
\hline & $\begin{array}{l}\text { biaya perawatan } \\
\text { gedung yang banyak } \\
(-4)\end{array}$ & \\
\hline & $\begin{array}{l}\text { polusi dengan level } \\
\text { tinggi }(-1)\end{array}$ & \\
\hline+14 & -17 & -1 \\
\hline
\end{tabular}

Skor akhir dari PMI adalah: $+13-8-1=-6$ (minus 6). Melihat hasilnya adalah minus, maka sebaiknya perusahaan mencari alternatif pendirian kantor di wilayah luar kota.

\section{Analisis Kekuatan Lapangan}

Teknik ini digunakan untuk melihat seluruh kekuatan yang mendukung dan menghambat sebuah keputusan. Dengan 
melakukan analisis terhadap faktor kekuatan, maka kita dapat memperkuat kekuatan yang mendukung sebuah keputusan, dan mengurangi pengaruh dari kekuatan yang menghalangi terbentuknya keputusan terbaik. Adapun langkah untuk teknik adalah:

1. Daftar seluruh kekuatan yang mendukung di satu kolom, dan kekuatan lain yang menghalangi kolom lainnya.

2. Tentukan skor untuk tiap kekuatan, dari 1 (lemah) sampai 5 (kuat)

3. Gambar diagram yang menunjukkan seluruh kekuatan, baik mendukung maupun menghalangi keputusan beserta skornya. Contoh soal

Seorang pemilik pabrik sedang memutuskan apakah dia akan memasang peralatan manufaktur baru atau tidak dari pabriknya. Sebagai manajer, Anda diminta untuk menganalisis faktor yang menghasilkan keputusan terbaik untuk pabrik. Berikut adalah penggunaan analisa kekuatan lapangan:

Gambar 4.1 analisis faktor

$\begin{array}{ccc}\begin{array}{c}\text { Kekuatan yang } \\ \text { mendukung }\end{array} & \text { Tujuan } & \text { Kekuatan yang } \\ \text { menghalangi }\end{array}$




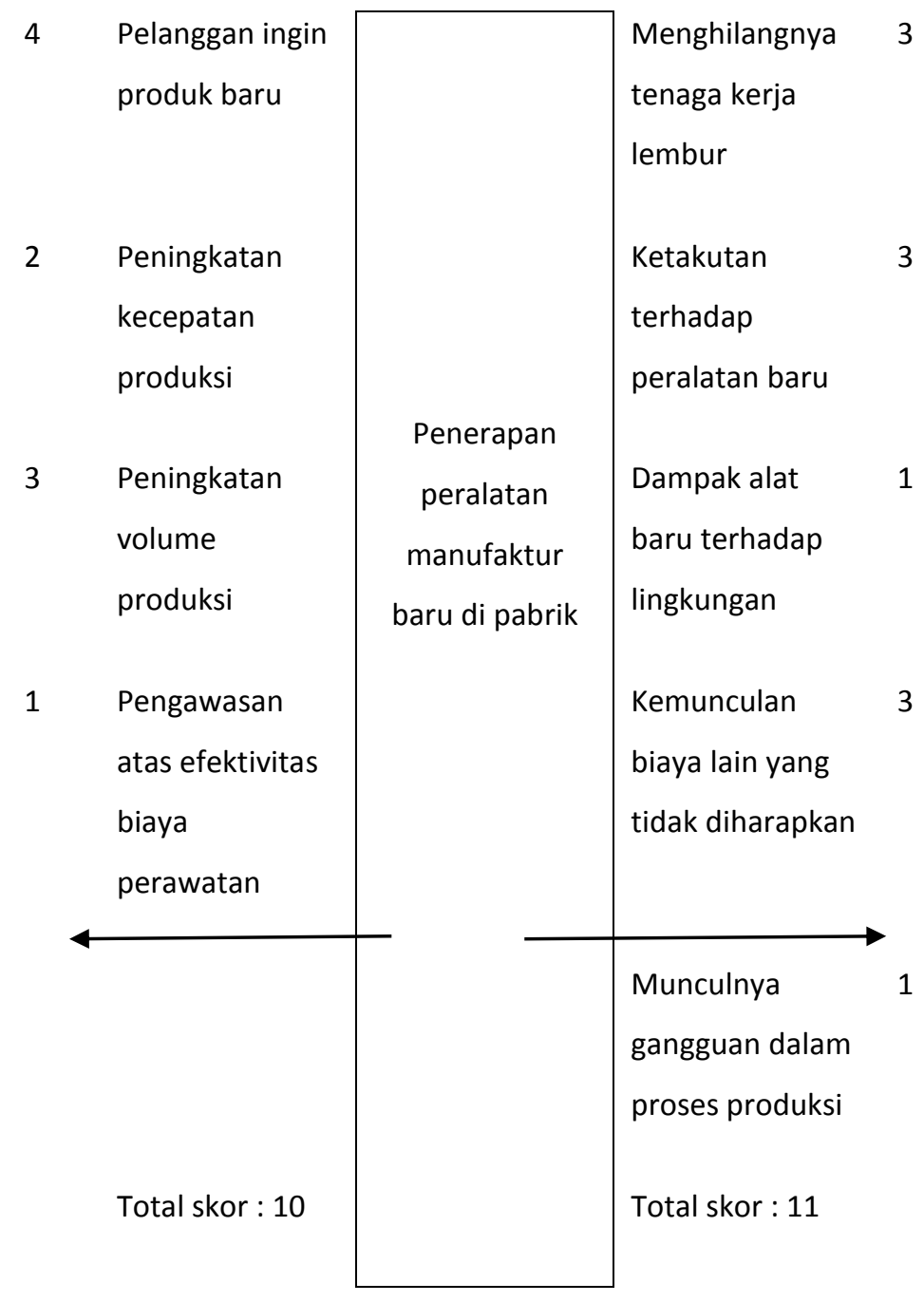

Langkah selanjutnya yang ditempuh adalah menanyakan apakah rencana yang ditetapkan akan diteruskan atau tidak. Teknik ini akan membantu kita dalam menentukan bagaimana meningkatkan 
peluang keberhasilan rencana tersebut. Untuk tujuan tersebut, kita akan berhadapan dengan dua pilihan:

1. Meningkatkan kekuatan pendukung agar tujuan dapat dicapai secara maksimal,

2. Mengurangi sejumlah kekuatan yang menghalangi tujuan yang telah ditetapkan.

Umumnya, solusi untuk menghasilkan keberhasilan pemilihan keputusan akhir adalah melalui langkah ke dua / menetralisir sisi negatif. Dalam kasus diatas, karyawan sebuah pabrik yang akan menggunakan teknologi baru memiliki resistance to change terhadap perubahan yang dilakukan. Mereka juga bertindak uncooperative jika kekuatan pendukung keputusan diterapkan.

Berdasarkan hasil analisis, Anda sebagai pengambil keputusan dapat melakukan sejumlah perubahan sbb:

1. Melakukan pelatihan karyawan. Cara ini akan meningkatkan biaya sebesar 1 , tetapi akan mengurangi tenaga kerja yang melakukan lembur sebesar 1 dan menghilangkan ketakutan terhadap penerapan teknologi baru sebesar 2 .

2. Penerapan teknologi akan menghasilkan kekuatan baru yang penting guna mendukung pertumbuhan bisnis sebesar 2 .

3. Mesin baru akan menghasilkan sejumlah jenis pekerjaan baru bagi karyawan, keuntungan ini bernilai 1 . 
4. Penerapan mesin akan meningkatkan upah meski menambah produktifitas. Dalam hal ini biaya akan bertambah 1, tetapi resiko kerja lembur berkurang sebanyak 2 .

5. Dampak alat baru terhadap lingkungan dapat dikurangi sebesar 1 dengan menerapkan sistem pengawasan polusi

Tabel 4.4 nilai kekuatan

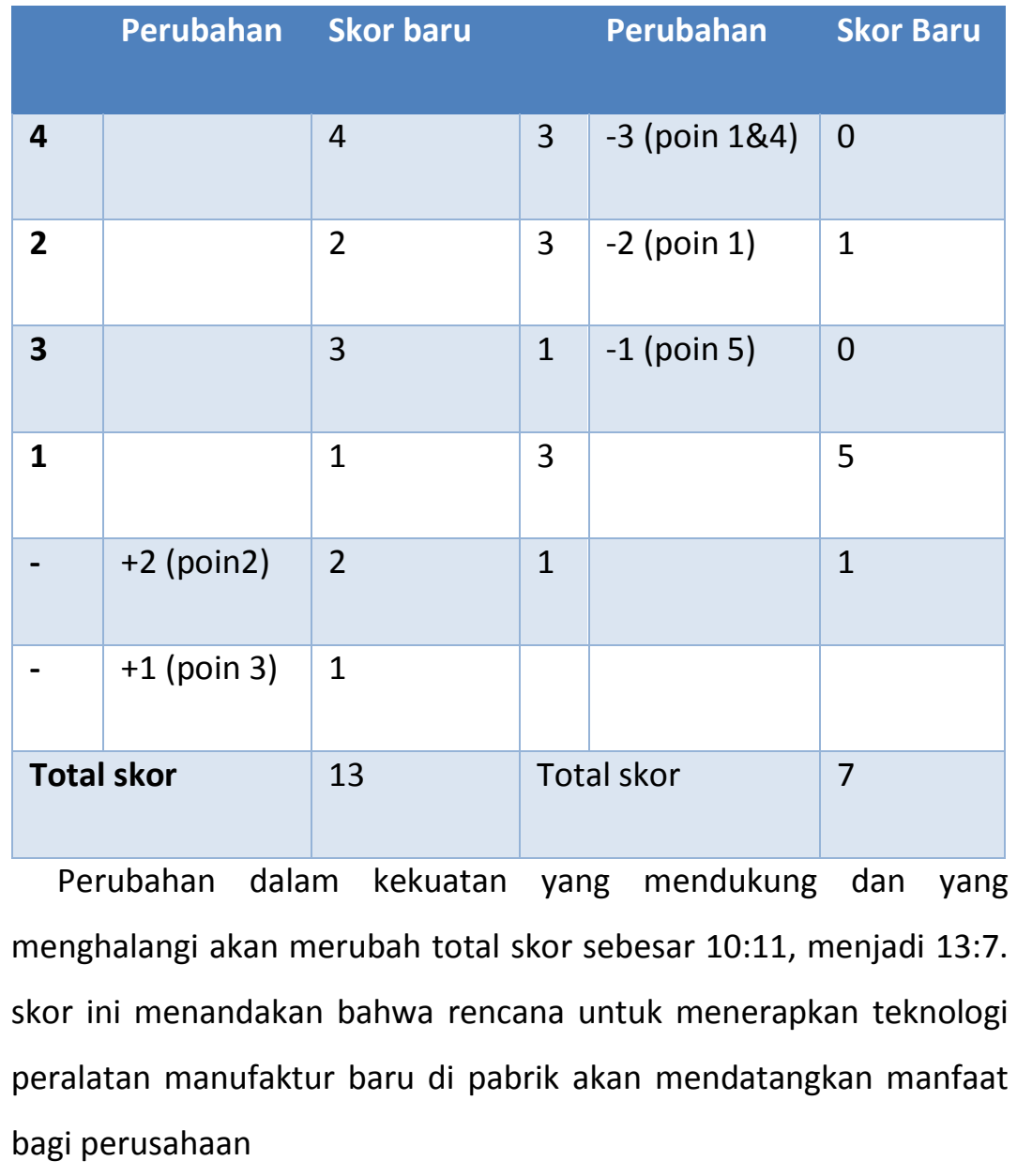




\section{E. Analisis Biaya Dan Manfaat}

Teknik analisis biaya dan manfaat merupakan teknik yang digunakan untuk memutuskan kemungkinan perubahan atas alternatif pilihan yang telah dipertimbangkan. Teknik ini cukup mudah digunakan karena hanya menghitung nilai perkiraan manfaat dari suatu tindakan, dan menguranginya dengan biaya yan akan muncul.

Analisis biaya dan manfaat umumnya dilakukan dengan menerapkan teknik analisis keuangan. Seluruh biaya dan manfaat dengan demikian dikonversi menjadi uang sebagai denominator utama. Perhitungan biaya dari sebuah peristiwa dilakukan dengan mendetail, kemudian kurangkan seluruh biaya tersebut pada biaya manfaat yang tersedia.

Contoh kasus

Perusahaan Anda sedang memutuskan untuk menerapkan sistem pengolahan penjualan dan sistem hubungan manajemen berbasis komputer. Masalah yang dihadapi adalah perusahaan hanya memiliki sedikit komputer, dan tenaga penjualan yang gagap teknologi (gaptek).

Manfaat yang didapat dari penerapan sistem berbasis komputer adalah tenaga penjualan dapat menghubungi lebih banyak 
pelanggan, sehingga dapat memberikan layanan yang lebih berkualitas serta dapat dipercaya. Manfaat lain adalah karyawan dapat bekerja secara lebih efektif dan efisien.

Bagaimana keputusan yang harus diambil? Dalam hal ini, salah satu teknik biaya-manfaat yang akan digunakan adalah periode pengembalian (Pay back period)

Biaya - biaya

- Biaya peralatan komputer baru:

1. 10 komputer baru beserta software @ Rp. 1.225 juta

2. 1 server Rp 1.750 juta

3. 3 printer \# Rp. 600 ribu

4. Instalasi dan pemasang kabel Rp. 2.3 juta

5. Software pendukung penjualan Rp. 7.5 Juta

- Biaya pelatihan:

1. Pengenalan terhadap komputer -8 orang @ Rp. 200 ribu

2. Kemampuan mengetik - 8 orang @ Rp. 200 ribu

3. Pelatihan sistem pendukung penjualan - 12 orang @ Rp. $350 \mathrm{Rb}$

- Biaya lain lain:

1. Waktu terbuang - 40 orang per hari @ 100 ribu / hari 
2. Hilangnya penjualan Rp 10 juta

3. Inefisiensi tugas pada awal penerapan sistem $\mathrm{Rp} 10$ juta

4. Total seluruh biaya Rp 55.8 juta

Manfaat - manfaat

a. Penghematan waktu pelayanan Rp 20 Juta / tahun

b. Peningkatan kemampuan promosi jarak jauh Rp 10 juta / tahun

c. Peningkatan efisiensi dan reliabilitas Rp 25 Juta / tahun

d. Peningkatan pelayanan Rp 15 juta / tahun

e. Peningkatan akurasi informasi pelanggan Rp 5 juta / tahun

f. Peningkatan kemampuan mengelola penjualan Rp 15 juta / tahun

Total seluruh manfaat Rp 90 juta / tahun

Periode pengembalian dana investasi Rp 55.8 / Rp $90=0.62$ juta / tahun atau kurang lebih dalam 8 bulan. Dari analisis cost / benefit, investasi layak dijalankan.

\section{F. Analisis Regresi dan Korelasi}

Analisis regresi adalah prosedur statistik untuk mengestimasi hubungan rata rata antar variabel yang tergantung (misal: penjualan) dan satu atau lebih variabel yang bebas (misal: harga dan iklan). 
Regresi juga dapat diartikan sebagai usaha memperkirakan perubahan di masa mendatang. Kesimpulannya, regresi akan mengemukakan tentang hal yang akan terjadi di masa depan untuk memberikan kontribusi dalam penentuan keputusan yang lebih baik.

Karena regresi mencari pengaruh antar hubungan variabel yaitu variabel $X$ ke $Y$, maka secara konsep sederhana bisa dipahami seperti di bawah ini:

Gambar 4.2 hubungan antar variabel

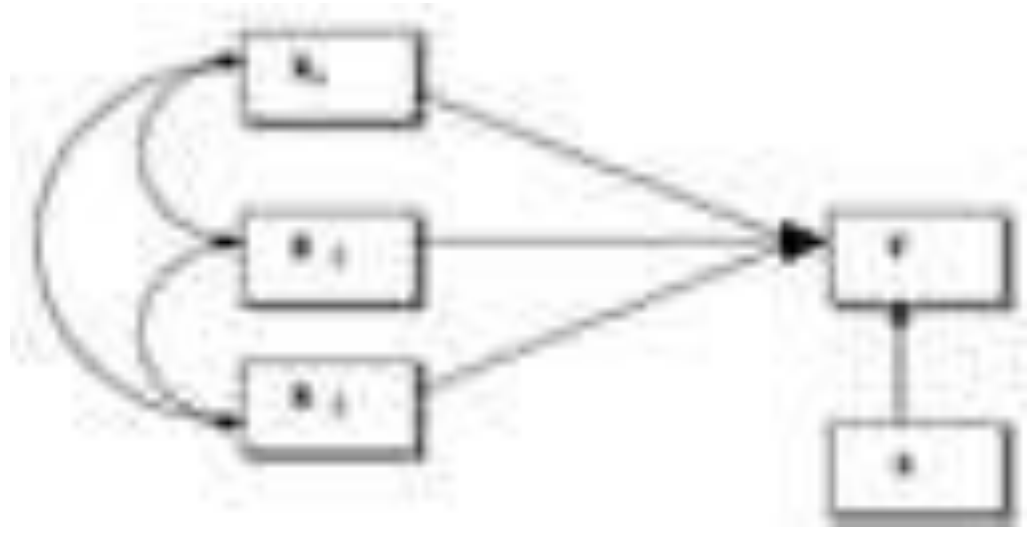

- $\quad \mathrm{X}$ adalah variabel bebas (exogen) atau independen. Dengan kata lain $\mathrm{X} 1, \mathrm{X} 2, \mathrm{X} 3$ memiliki derajat pengaruh tertentu terhadap Y.

- Y adalah variabel terikat (endogen) atau dependen.

- E adalah variabel sisa (residu).

Dalam analisis regresi terdapat beberapa asumsi sebagai landasan dalam pengambilan keputusan: 

a. Data yang dianalisis adalah jenis interval dan ratio
b. Data yang dipilih secara acak
c. Data yang dihubungkan berdistribusi normal
d. Data yang dhubungkan berpola linier
e. Data yang dihubungkan mempunyai pasangan yang sama sesuai dengan objek yang sama.

Analisis korelasi adalah sejauh mana hubungan antar variabel yang diteliti. Kuatnya hubungan antar variabel dihasilkan dari analisis korelasi dapat diketahui berdasarkan besar kecilnya koefisien korelasi yang besarannya berkisar pada minus $1(-1)$ s/d plus $1(+1)$

Korelasi akan sangat berhubungan dengan regresi. Bila koefisien korelasi ( $r$ ) tinggi, umumnya koefisien regresi (b) juga tinggi, begitu pula sebaliknya.

Ketika korelasi hanya melibatkan dua variabel saja, kita menyebutnya sebagai korelasi sederhana. Ketika masalah korelasi melibatkan lebih dari dua variabel, maka kita bisa menyebutnya sebagai masalah korelasi berganda.

Secara umum, terdapat dua koefisien korelasi yang umum digunakan dalam konteks pengambilan keputusan, yaitu:

\section{Koefisien Korelasi Pearson}

Korelasi ini dikemukakan oleh Karl Pearson tahun 1900. kegunanaannya untuk mengetahui derajat hubungan antara 
variabel bebas dengan variabel terikat. Formula yang paling sering digunakan dalam menghitung korelasi pearson adalah Korelasi Pearson Product Moment / KPPM.

KPPM digunakan untuk mengkaji harga atau pergerakan yang terjadi, yaitu bagaimana variabel $\mathrm{X}$ dan $\mathrm{Y}$ dan seberapa kuat hubungannya.

Adapun rumus dari KPPM adalah sebagai berikut:

$$
r=\frac{n \cdot\left(\sum X Y\right)-\left(\sum X\right)\left(\sum Y\right)}{\sqrt{\left(n \cdot \sum X^{2}-\left(\sum X\right)^{2}\right) \cdot\left(n \cdot \sum Y^{2}-\left(\sum Y\right)^{2}\right)}}
$$

KPPM dilambangkan dengan $(r)$ dengan ketentuan nilai $r$ tidak lebih dari harga $(-1 \leq r \leq+1)$. Apabila nilai $r=-1$ artinya korelasi negatif sempurna; $r=0$ artinya tidak ada korelasi; dan $r=1$ berarti korelasinya sangat kuat.

Interpretasi nilai $r$ dapat dikategorikan sebagai berikut:

Tabel 4.5 tabel interpretasi

Interval Koefisien

$0.80-1.000$
Tingkat Hubungan

Sangat Kuat 

$0.60-0.799$
Kuat
$0.40-0.599$
Cukup Kuat
$0.20-0.399$
Rendah
$0.00-0.199$
Sangat Rendah

Contoh Soal KPPM (r) :

Berikut adalah data pengeluaran dan pemasukan 6 bulan dari usaha bisnis CV Furniture Berdikari di bawah ini, dan selanjutnya hitunglah apakah terdapat hubungan yang signifikan atau tidak diantara pengeluaran dan pemasukan pada CV tersebut:

Tabel 4.6 contoh soal KPPM 1

\begin{tabular}{|l|l}
\hline Bulan & Pengeluaran (X) \\
\hline
\end{tabular}

Pemasukan (Y)

Januari

35

160

Februari

40

189 
Berdasarkan data tersebut maka terdapat dua hipotesis atau dugaan sementara yang bisa dihasilkan untuk segera dibuktikan:

Hipotesis 1 (Ha) : terdapat hubungan yang signifikan antara pengeluaran dan pemasukan pada CV Furniture Berdikari semenjak bulan Januari s/d Juni 2014.

Hipotesis 2 (Ho) : tidak ada hubungan yang signifikan antara pengeluaran dan pemasukan pada CV Furniture Berdikari semenjak bulan Januari s/d Juni 2014.

Jika kita ingin membuktikan mana yang paling tepat diantara hipotesis 1 dan hipotesis 2, Anda harus melakukan pengujian secara rumus KPPM $(r)$, yang terlebih dahulu dilakukan perhitungan secara tabel sebaga berikut: 
Tabel 4.7 contoh soal KPPM 2

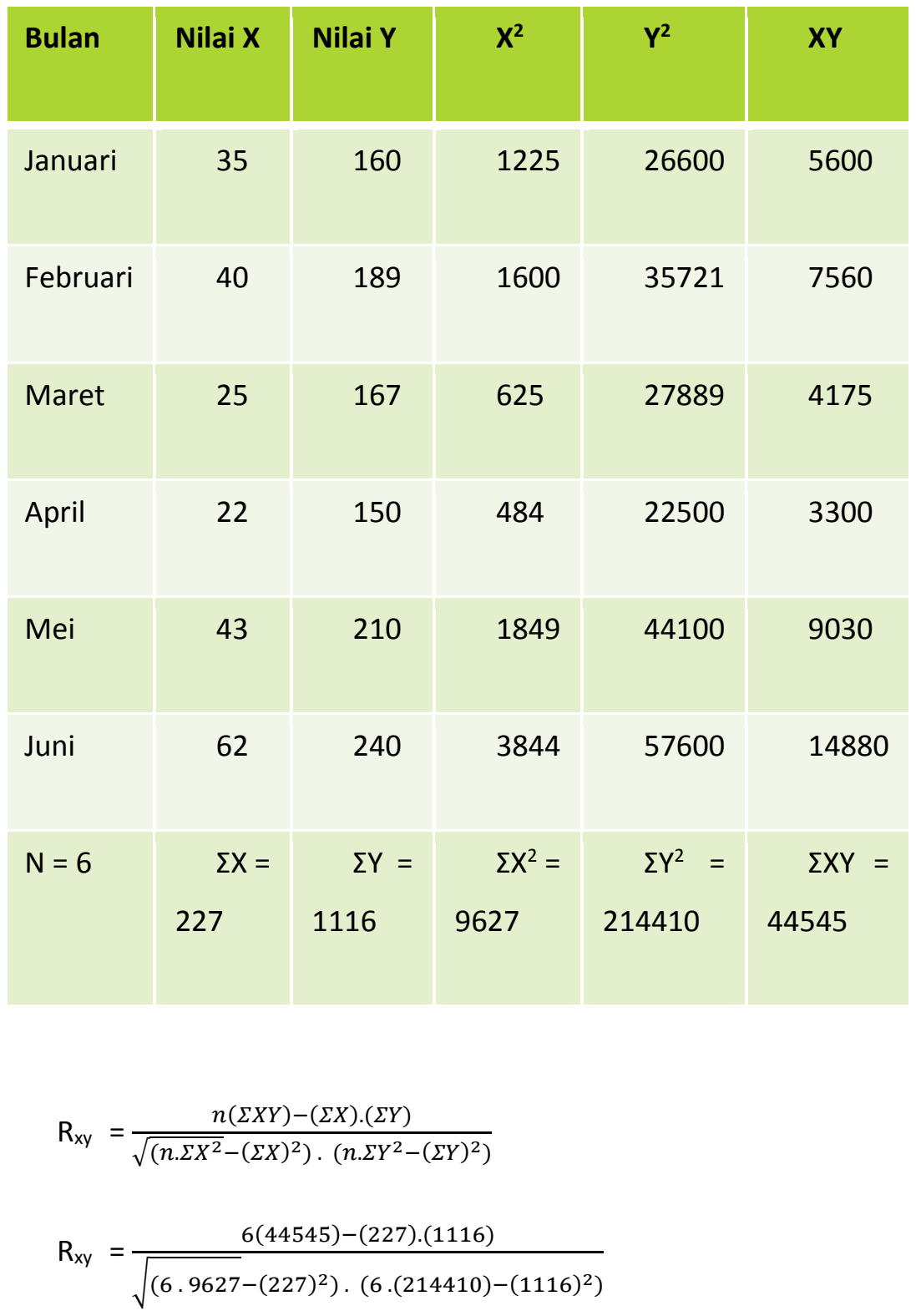




$$
\begin{aligned}
& R_{x y}=\frac{267270-253332}{\sqrt{(6233) \cdot(41004)}} \\
& R_{x y}=\frac{13938}{\sqrt{255577932)}} \\
& R_{x y}=\frac{13938}{15987} \\
& R_{x y}=0.871844 \text { atau } 0.87
\end{aligned}
$$

Berdasarkan hasil perhitungan, dapat disimpulkan bahwa RXY dengan hasil 0.861 adalah termasuk dalam kategori sangat kuat, dengan kata lain Hipotesis 1 ( $\mathrm{Ha}$ ) diterima atau terdapat hubungan yang signifikan.

Hasil ini dapat dijadikan keputusan untuk menganggap bahwa CV Furniture Berdikari mendapatkan laba dalam 6 bulan masa kerjanya.

2. Koefisien korelasi Spearman Rank

Kalau pada korelasi product moment, sumber data untuk variabel yang akan dikorelasikan adalah sama dan data yang dikorelasikan adalah data interval atau rasio.

Maka dalam korelasi Spearman Rank, sumber data yang akan dikonversikan dapat berasal dari sumber yang tidak sama dan jenis data yang dikonversikan adalah data ordinal. 
Jadi korelasi Spearman Rank bekerja dengan data ordinal atau berjenjang atau ranking, dan bebas distribusi.

Contoh Soal Spearman Rank

Ada 10 orang responden yang diminta untuk mengisi daftar pertanyaan tentang Motivasi dan Prestasi dalam sebuah kantor. Jumlah responden yang diminta mengisi daftar pertanyaan itu 10 karyawan, masing-masing diberi nomor $1,2,3,4,5,6,7,8,9,10$. Nilai yang diberikan oleh kesepuluh responden tentang Motivasi dan Prestasi itu diberikan pada tabel berikut. Yang ingin diketahui adalah apakah terdapat hubungan antara Motivasi dengan Prestasi.

Tabel 4.7 contoh soal spearman 1

\begin{tabular}{|l|l|l|}
\hline Responden & Skor Motivasi & Skor Prestasi \\
\hline 1 & 9 & 8 \\
\hline 2 & 6 & 7 \\
\hline 3 & 5 & \\
\hline 4 & 5 & 6 \\
\hline
\end{tabular}




\begin{tabular}{|l|l|l|}
\hline 5 & 4 & 5 \\
\hline 6 & 3 & 4 \\
\hline 7 & & \\
\hline 8 & 2 & 2 \\
\hline 9 & 8 & \\
\hline 10 & 7 & 9 \\
\hline & 6 & \\
\hline
\end{tabular}

Data tersebut diperoleh dari sumber berbeda yaitu Motivasi (Xi) dan Prestasi (Yi). Karena sumber datanya berbeda dan berbentuk ordinal, maka untuk menganalisis digunakan Rank Spearman yang rumusnya adalah:

$$
r_{s}=1-\frac{6 \sum d_{i}^{2}}{n\left(n^{2}-1\right)}
$$

Berdasarkan data tersebut maka terdapat dua hipotesis atau dugaan sementara yang bisa dihasilkan untuk segera dibuktikan: 
Hipotesis $1(\mathrm{Ha})$ : terdapat hubungan yang signifikan antara antara variabel Motivasi dan Prestasi

Hipotesis 2 (Ho) : tidak ada hubungan yang signifikan antara antara variabel Motivasi dan Prestasi.

Korelasi Spearman rank bekerja dengan data ordinal. Karena jawaban responden merupakan data ordinal, maka data tersebut harus diubah terlebih dahulu dari data ordinal dalam bentuk ranking yang caranya dapat dilihat dalam tabel berikut

Tabel 4.8 contoh soal spearman 2

\begin{tabular}{|l|l|l|l|l|l|l|}
\hline $\mathbf{R}$ & $\mathbf{X i} /$ Nilai & $\mathbf{Y i} /$ Nilai & Peringkat & Peringkat & $\mathbf{d i}$ & $\mathbf{d i}^{2}$ \\
\hline & Motivasi & Prestasi & $\mathbf{X i}$ & & \\
\hline 1 & 9 & 8 & 1 & 3 & -2 & 4 \\
\hline 2 & 6 & 7 & 5.5 & 5 & 0.5 & 0.25 \\
\hline 3 & 5 & 6 & 7 & 6.5 & 0.5 & 0.25 \\
\hline 4 & 7 & 8 & 3.5 & 3 & 0.5 & 0.25 \\
\hline 5 & 4 & 5 & 8 & & \\
\hline
\end{tabular}




\begin{tabular}{|l|l|l|l|l|l|l|}
\hline 6 & 3 & 4 & 9 & 0 & 0 \\
\hline 7 & 2 & 2 & 10 & 10 & 0 & 0 \\
\hline 8 & 8 & 9 & 2 & 1 & 1 & 1 \\
\hline 9 & 7 & 8 & 3.5 & 3 & 0.5 & 0.25 \\
\hline 10 & 6 & 6 & 5.5 & 6.5 & -1 & 1 \\
\hline
\end{tabular}

Sebagai interpretasi, hasil akhir perlu dibandingkan dengan tabel nilai-nilai $\rho$ (dibaca: rho). Dari tabel nilai $\rho$ terlihat bahwa untuk $n=$ 10, dengan derajat kesalahan $5 \%$ diperoleh harga 0,648 dan untuk 1 $\%=0,794$. 


$$
\begin{array}{ll}
\text { Rs } & =1-\frac{6 \cdot \sum b i^{2}}{n \cdot\left(n^{2}-1\right)} \\
\text { Rs } & =1-\frac{6.7}{10 \cdot\left(10^{2}-1\right)} \\
\text { Rs } & =1-\frac{42}{10 \cdot 99} \\
\text { Rs } & =1-\frac{42}{990} \\
\text { Rs } & =1-0.04 \\
\text { Rs } & =0.96
\end{array}
$$

Hasil $\rho$ hitung ternyata lebih besar dari $\rho$ tabel

Derajat kesalahan $5 \% \ldots . .0,96>0,648$

Derajat kesalahan $1 \% \ldots . .0,96>0,794$

Dengan demikian hipotesis nol (Ho) ditolak dan hipotesis alternatif $(\mathrm{Ha})$ diterima. Atau dengan kata lain bahwa variabel Motivasi mempunyai hubungan yang signifikan dengan Prestasi.

\section{G. Analisis Forecasting Moving Average}

Analisis forecasting adalah analisis peramalan penjualan yang mungkin bisa terjadi di masa mendatang. Penggunaan analisis ini menjadi sangat penting karena dengan analisis ini kita menilai sejauh mana sebuah keputusan tersebut menjadi efektif dan efisien, dan bagaimana mengantisipasi sebuah permasalahan yang akan terjadi nantinya. 
Untuk mendapatkan data yang benar benar akurat dan dapat dipercaya, Anda dapat menggali data dari sumber eksternal dan internal. Secara umum sumber data eksternal dalam forecasting dibagi dua:

A. Data primer, yaitu data yang bersumber dari wawancara, atau diskusi dengan pihak terkait. Bentuk mendapatkan data ini juga bisa dilakukan melalui kuesioner yang berisi poin pertanyaan yang dijawab responden.

B. Data sekunder, yaitu data yang bersumber dari laporan tertulis, seperti laporan penjualan, laporan keuangan, kajian literatur, atau dokumen sejenis yang dinyatakan layak untuk digunakan untuk sumber data forecasting.

Dalam analisis metode moving average, kita akan melihat kondisi penjualan rata rata yang terjadi selama 1 (satu) periode waktu tertentu (misal: 1 tahun, 5 tahun, atau 10 tahun). Namun umumnya, metode ini digunakan untuk melihat pergerakan rata rata penjualan dalam waktu 1 tahun. Untuk menghitungnya, kita menggunakan rumus:

$$
\bar{x}(\text { mean })=\Sigma \mathrm{Xi} / \mathrm{n}
$$


Tabel 4.9 contoh soal forecasting

\begin{tabular}{|l|l|}
\hline Tahun 2012 & Penjualan keripik nangka (kg) \\
\hline Januari & 65 \\
\hline Februari & 72 \\
\hline Maret & 76 \\
\hline April & 70 \\
\hline Mei & 85 \\
\hline September & 94 \\
\hline Juni & 96 \\
\hline
\end{tabular}


Jawab:

Dengan menggunakan rumus diatas, maka:

$$
\begin{aligned}
& \bar{x}=65+72+76+70+85+86+90+82+94+92+90+93 / 12 \\
& \bar{x}=995 / 12=82,9166 \text { atau } 82,92
\end{aligned}
$$

Jadi nilai rata rata penjualan keripik nangka tahun 2012 adalah 82,92 .

\section{E. Soal Soal}

1. Anda adalah seorang pengusaha yang bergerak pada industri kreatif. Usaha Anda berkembang pesat, dan setiap 2 bulan Anda merekrut paling tidak 1 orang karyawan untuk memberikan pelayanan yang prima kepada konsumen Anda.

Saat ini Anda telah memiliki 20 orang karyawan, dan diperkirakan memiliki lebih dari 30 karyawan tahun depan. Agar usaha Anda berkembang lebih besar lagi, Anda merencanakan untuk pindah ke lokasi yang lebih strategis. 
Anda menemukan 3 lokasi bangunan yang representatif bagi usaha Anda:

- Toko A (bangunan baru dengan dua lantai \& sangat mendukung untuk usaha kreatif, kapasitas karyawan 30 orang, harga sewa tinggi, sewa bangunan tidak dapat dicicil, lokasi di tengah kota, berdekatan dengan konsumen potensial, rawan banjir, keamanan terjaga).

- Toko B (bangunan gudang tua $\&$ belum mendukung untuk usaha kreatif, kapasitas karyawan 100 orang, harga sewa sedang, sewa bangunan dapat dicicil, lokasi di tengah kota, berdekatan dengan konsumen potensial dan supplier, bebas banjir, keamanan rawan).

- Toko C (bangunan baru dengan 3 lantai \& kurang lebih mendukung untuk usaha kreatif, kapasitas karyawan 100 orang, harga sewa sedangsewa bangunan dapat dicicil, bangunan, lokasi di pinggiran kota, berdekatan dengan supplier, bebas banjir, keamanan terjaga).

Buatlah analisis kekuatan lapangannya!

2. Anda adalah seorang pengusaha yang bergerak pada industri kreatif. Usaha Anda berkembang pesat, dan setiap 2 bulan Anda merekrut paling tidak 1 orang karyawan untuk memberikan pelayanan yang prima kepada konsumen Anda. Saat ini Anda telah memiliki 20 orang karyawan, dan diperkirakan memiliki 
lebih dari 30 karyawan tahun depan. Agar usaha Anda berkembang lebih besar lagi, Anda merencanakan untuk pindah ke lokasi yang lebih strategis.

Anda menemukan 3 lokasi bangunan yang representatif bagi usaha Anda, dan memutuskan menggunakan Toko B sebagai kantor Anda:

Toko B (bangunan gudang tua \& belum mendukung untuk usaha kreatif, kapasitas karyawan 100 orang, harga sewa sedang, sewa bangunan dapat dicicil, lokasi di tengah kota, berdekatan dengan konsumen potensial dan supplier, bebas banjir, keamanan rawan).

Buatlah Analisis Force Fieldnya! 


\section{DAFTAR PUSTAKA}

Barry \& Heizer. (2001). Prinsip Prinsip Manajemen Operasi (terjemahan). Jakarta: Salemba Empat.

Dermawan, Rizky. (2016). Pengambilan Keputusan; Landasan Filosofis, Konsep, dan Aplikasi. Bandung: Alfabeta.

Fahmi, Irham. (2016). Teori dan Teknik Pengambilan Keputsan. Jakarta: Rajawali Press.

Rangkuti, Freddy. (1998). Analisis SWOT Teknik Membedah Kasus Bisnis, Reorientasi Konsep Perencanaan Strategis. Jakarta: Gramedia.

Riduwan \& Akdon. (2012). Rumus dan Data dalam Analisis Statistika. Bandung: Alfabeta.

Sugiyono. (2009). Statistik untuk Penelitian. Bandung: Alfabeta.

Suyadi, Prawirosentono. (2002). Bahasan Komprehensif Strategi Pengambilan Keputusan Bisnis. Jakarta: Bumi Aksara 


\section{BIODATA PENULIS}

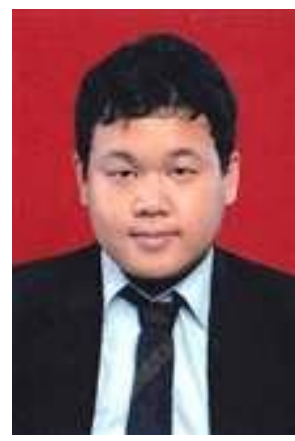

Rizky Eka Febriansah, S.Mb., M.SM. lulus S1 di Program Studi Manajemen Bisnis di Fakultas Manajemen Bisnis Telekomunikasi Universitas Telkom (UTELK) Bandung Tahun 2011. Lulus S2 di Program Magister Science Management Universitas Airlangga (UNAIR) Surabaya Tahun 2015. Saat ini, penulis adalah Dosen Tetap sekaligus menjabat sebagai Kepala Laboratorium periode 2016 2018 pada Program Studi Manajemen Fakultas Ekonomi dan Bisnis Universitas Muhammadiyah Sidoarjo. Mengampu mata kuliah Ekonomi Pembangunan, Manajemen Sumber Daya Manusia, Teori Pengambilan keputusan, dan Sistem Informasi Manajemen. Penulis aktif di dunia organisasi, terlibat pada Himpunan Pengusaha Muda Indonesia (HIPMI) dan Forum Manajemen Indonesia (FMI). Penulis juga aktif dalam menulis jurnal ilmiah dan pernah tampil pada 5 konferensi pada kurun waktu 2016 - 2019, 7 konferensi nasional dan 2 konferensi Internasional. 


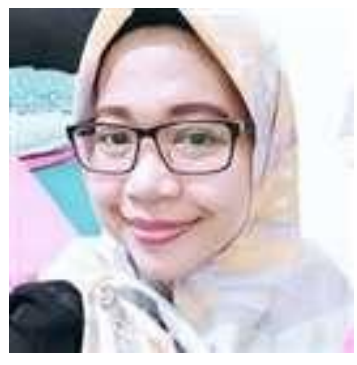

Dewi Ratiwi Meiliza, SE, MM. Lahir pada 15 Pebruari 1984 di Bangkalan, merupakan anak ke 3 dari 6 bersaudara. Menempuh S1 nya pada Manajemen Fakultas Ekonomi dan S2 nya pada Magister Manajemen pada Universitas Persada Indonesia Yai. Penulis merupakan dosen tetap Universitas Muhammadiyah Sidoarjo, mengampu mata kuliah Manajemen Keuangan, Manajemen Strategi, dan Teori Pengambilan Keputusan. Peunulis juga menjabat sebagai Unit Jaminan Mutu Prodi Manajemen UMSIDA periode 2018 - 2020. Sebelum memutuskan untuk berkarir sebagai pengajar pada akhir tahun 2016, penulis pernah memiliki karir pada PT. Nestle . 